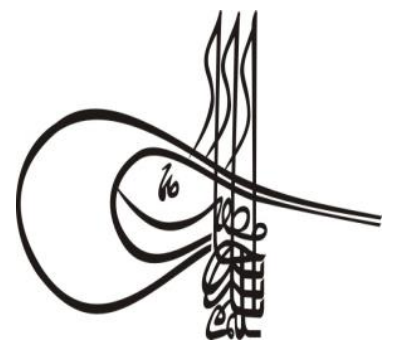

Received/Geliş: 17.10.2019

\section{Turkísh Studíes}

Volume 14 Issue 7, 2019, p. 3631-3656

DOI: 10.29228/TurkishStudies. 39342

ISSN: $1308-2140$

Skopje/MACEDONIA-Ankara/TURKEY

Research Article / Araştırma Makalesi

Article Info/Makale Bilgisi

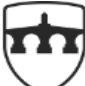

INTERNATIONAL

BALKAN

UNIVERSITY

EXCELLENCE FOR THE FUTURE IBU.EDU.MK

$\checkmark$ Accepted/Kabul: 20.12.2019

Go Report Dates/Rapor Tarihleri: Referee 1 (24.10.2019)- Referee 2 (06.11.2019)

This article was checked by iThenticate.

\title{
TÜRK VE KOMŞU TOPLULUKLARDA KÜLTÜREL ÇOCUK OYUNLARI
}

\author{
Döndü Neslihan $B A Y^{*}-$ Yalçın $B A Y^{*}$
}

\begin{abstract}
öz
Türk Dünyası Çocuk Oyun ve Oyuncakları Projesi (TÜDÇOOP) kapsamında gerçekleştirilen saha araştırmalarının amacı, Türk ve komşu topluluklarda geçmişten günümüze oynanan oyunların ortaya konulmasidır. Araştırmada nitel araştırma yöntemlerinden görüşme yöntemi kullanılmıştır. Saha araştırması süresince toplam 17 ülke/bölgede (Kazakistan, Kirgızistan, Tacikistan, Özbekistan, Moğolistan, Tuva, Hakasya, Altay, Yakutistan, Azerbaycan, Dağıstan/Nogaylar, Kabardey-Balkar, Karaçay-Çerkes, Çuvaşistan, Tataristan, Başkurdistan ve Kuzey Kıbrıs Türk Cumhuriyeti), 33 şehir, 12 ilçe, 42 köy ve 32 okul ziyareti gerçekleştirilmiştir. Bu ziyaretlerde 100 katılımcı ile görüșme yapılmıștır. Verilerin analizinde betimsel ve içerik analiz teknikleri kullanılmıştır. Araştırma sonuçları incelendiğinde katılımcıların geçmişte oynadıkları 396 oyunu hatırlayabildikleri görülmüştür. Bu oyunlardan 112 oyun adının sadece bir ülkede ifade edildiği, geriye kalan 284 oyun adının ise benzer oyunlar olarak ülkelerde tekrar edildiği görülmüştür. Araştırmada tanımlanan oyunların çeşitliği ele alındığında 173 farklı oyun belirlenmiştir. Bu oyunların çoğunlukla dış mekânlarda ve 5 saatten daha fazla süreyle oynandığı, oyunlarda kendi yaptıkları oyuncakların kullanıldığı, bu oyunların arkadaş, abla/ağabey, anne/babalar ve aile büyükleri vasıtasılla öğrenildiği bildirilmiştir. Bu oyunlardan 248'nin (\%63) günümüzde unutulduğu ve çocuklar tarafından oynanmadığının düşünüldüğü, oyunların unutulmaması için; okullarda öğretilmesi, Türk toplumlarından öğrenilmesi, teknoloji kullanımının sınırlandırılması, dede/ninelerin oyunları anlatması, kültürel oyuncak üretimi, okul öncesi dönemde kazandırılmas1, kitap yazılması, ödüllü yarışmaların düzenlenmesi, kurultay, sempozyum düzenlenmesi, kültür merkezlerinin kullanılması, kültür merkezlerinin kullanılması, millî
\end{abstract}

Doç. Dr., Eskişehir Osmangazi Üniversitesi, E-posta: bayneslihan @ gmail.com

Doç. Dr., Anadolu Üniversitesi, E-posta: yalcinbay73@ gmail.com 
bayramlarda oynatılması, kanunlar yoluyla korunmas1, sokakta oyunun desteklenmesi temalarının ortaya çıktığı görülmüştür.

Anahtar Kelimeler: Çocuk oyunları, oyuncak, kültür, unutulmuş oyunlar, eğitim.

\title{
CULTURAL CHILDREN'S GAMES IN TURKISH AND NEIGHBORING COMMUNITIES
}

\begin{abstract}
The aim of the research carried out within the scope of the Turkish World Children's Games and Toys Project (TWCGATO) is to reveal the games played in Turkish and neighboring communities in the past. The method used in the research is interview method which is one of the qualitative research methods. During the research, 17 countries / regions (Kazakhstan, Kyrgyzstan, Tajikistan, Uzbekistan, Mongolia, Tuva, Khakassia, Altai, Yakutia, Azerbaijan, Dagestan/Nogai, Kabardino-Balkaria, Karachay-Cherkessia, Chuvashia, Tatarstan, Bashkortostan and Turkish Republic of Northern Cyprus), 33 cities, 12 districts, 42 villages and 32 schools have been visited and interviews have been conducted with 100 participants. Descriptive and content analysis techniques were used in the analysis of the data. According to the results of the research, 396 games played in the past have been mentioned by the participants. It was seen that 112 games have been mentioned in only one country and the remaining 284 games have been repeated in various countries as similar games. Regarding the type of the games mentioned in the research, a total of 173 different types of games were found in the study. These games are mostly played outside and for more than 5 hours; children mostly use their own-made toys in the games; these games are learned through friends, brothers/sisters, parents and family elders; and 248 games (63\%) were thought to be forgotten today and not played by children. The themes emerged to prevent the games from being forgotten are: teaching them in schools, limiting the use of technology, grandfather/grandmothers talks about the games, producing cultural toys, learning from Turkish communities, teaching the games in pre-school period, writing books, organizing award-winning competitions, organizing congress and symposium, using cultural centers, playing them in national holidays, protecting the games by law, supporting playing game on the street.
\end{abstract}

\section{STRUCTURED ABSTRACT}

\section{Introduction}

Games, which is a cultural heritage, has now started to lose importance and being forgotten (Arslan, 2017; Öz Pektaş, 2017; Özden Gürbüz, 2016; Tören, 2011; Toksoy, 2010; Esen, 2008; Artar, Onur and CCelen, 2004) along with the changing lives of communities (Öz Pektaş, 2017). The reasons of the failure to play the games that make up the identity of communities should be questioned (Arslan, 2017) and children's games should be protected by recording (Artar, Onur and 
Çelen, 2004) (Özden Gürbüz, 2016). It is important to examine the games within the framework of historical and sociocultural elements and to determine continuity and break in cultural transference (Rossie, 2005). In this context, it is necessary to determine the games played in the past, the toys and their characteristics (Arslan, 2017) and to protect our cultural heritage by conducting researches on a wide geography covering Turkish and neighboring communities (Bay, Turan, Bay, 2015). The purpose of this research is to reveal the type of the games played in Turkish and neighboring communities in the past. For this general purpose, the following research questions were identified;

Regarding Turkish and neighboring communities;

- What are the games played in the past?

- What are the features of these games?

- What are the views on how these games are learned?

- What are the views about which games are forgotten today?

- What are the views to prevent these games from being forgotten?

\section{Methodology}

Semi-structured interview method, which is one of the qualitative research methods, was used to reveal the games played in Turkish and neighboring communities in the past. During the research, 17 Turkish and neighboring countries (Kazakhstan, Kyrgyzstan, Tajikistan, Uzbekistan, Mongolia, Tuva, Khakassia, Altai, Yakutia, Azerbaijan, Dagestan/Nogai, Kabardino-Balkaria, Karachay-Cherkessia, Chuvashia, Tatarstan, Bashkortostan and Turkish Republic of Northern Cyprus), a total of 33 cities, 12 districts, 40 villages and 33 schools have been visited. Interviews have been conducted with a total of 100 participants, 56 females and 46 males. Data were collected over a period of 6 months, in two years, during 3 months of summer season each year. Descriptive and content analysis was used in the analysis of the obtained data.

\section{Results}

In the research conducted to reveal the games played in the Turkish and some neighboring countries in the past, 17 countries, 33 cities, 12 districts, 40 villages and 33 schools were visited, interviews were conducted with 100 participants. During the interviews, 396 cultural games played in the past were mentioned. Of these games, it was seen that 112 game names were expressed in only one country. The interviews conducted with participants over 60 years in all countries except the TRNC revealed that World War II had a significant impact and few of the participants were able to say that they had played games in their childhood. During this period where the Turkish communities living in Karachay and have been were deported, the participants had to help their families in their childhood due to poverty and misery; but they stated that they had played games at every opportunity they found when they went to the fields or grazing animals. Another factor on the past games is the independence of Azerbaijan, Kazakhstan, Kyrgyzstan, Uzbekistan and Tajikistan after the collapse of the Soviet Union. The participants stated that they could not preserve their culture before they became independent and that they tried to recall and preserve 
their cultural values after independence. In the TRNC, the participants stated that they could not protect their games sufficiently during the UK administration, which has lasted for 100 years.

Another important result of the study is that the same game names (jacks, duck duck goose, etc.) have been found to be repeated 284 times in the countries. Cultural games are similar in terms of the reflection of the unity in expression and thought, although there are located in different geographies within the Turkish world (Gökşen, 2014; Esen, 2008). In this context, if the field of research is expanded, the similarity of the cultural games is expected to increase in these countries, which are known to have common cultural values in the historical past.

13 different themes emerged regarding the prevention of forgetting the games played in the past, among them the themes of teaching games in schools and limiting the use of technology were the mostly expressed ones. Moreover, grandfather/grandmothers talk about the games, producing cultural toys, learning from Turkish communities, teaching the games in pre-school period, writing books, organizing award-winning competitions, organizing congress and symposium, using cultural centers, playing them in national holidays, protecting the games by law, supporting playing game on the street were also mentioned.

The results of the study revealed a scheme in terms of seeing the current situation of cultural games and it is believed that they are at serious risk of extinction. In this direction, the themes emerging from the statements of the participants are very important in terms of the measures that can be taken.

\section{Recommendations}

Based on the results of the research, the following suggestions were submitted:

- Carrying out field researches covering other Turkish and neighboring societies in order to reveal cultural games more comprehensively;

- Writing various books for the use of the games in educational institutions, in addition to the compilation of the games;

- Preparing toys with original designs, which will make cultural games attractive to children and preparing them in kits for individual and school use;

- Arranging the programs of various educational levels to include direct teaching as well as the use of cultural games as a method in education starting from pre-school education;

- Opening courses on the teaching of cultural games in Public Education Centers, whose purpose of establishment include cultural transfer;

- Providing the necessary support for families through family education seminars, for the transfer of cultural games to their children; 
- Taking decisions about playing cultural games at national holidays in educational institutions and to organize competitions within or between institutions;

- Preparing safe environments in residential areas and parks to encourage children to play cultural games.

Keywords: Children's games, toys, culture, forgotten games, education.

\section{Giriş}

Oyun, çocuğun kendi iç dünyasını yansıttığı ve gerçek dünya ile bağlantı kurduğu en etkili iletişim aracıdır (Bozkaya, 1990). Çocukların özgürce kendini ifade edebildiği, severek ve isteyerek içinde yer aldığı oyun (Sun ve Seyrek, 1997), çocuğun dünyayı keşfetmesini sağlayan en önemli öğrenme yolu olarak da tanımlamaktadır (Tuğrul, 2010; Kayar, 2008; Koçyiğit, Tuğluk ve Kök, 2007; Spodek \& Saracho, 2003). Oyunun çocuklar üzerinde öğrenmeyle birlikte gelişimlerini ve beceri kazanmalarını destekleyen önemli bir etkisi vardır (Girmen, 2012; Adak Özdemir \& Ramazan, 2012; Koçyiğit, Tuğluk ve Kök, 2007). Dolayısıyla çocuk, oyun sayesinde kendini yaşama hazırlamaktadır (Huizinga ve Ludens, 1995).

Oyun aynı zamanda çocuğun toplumun bir bireyi olarak kişilik ve kimlik kazanımını sağlayan, çocuğun kendi öz benliğinin farkına varmasını sağlayan, sevgiden sonra ikinci önemli temel ihtiyacıdır (Yörükoğlu, 2004). Topluma uygun kimlik kazanımını sağlayan oyunun, toplumun değerlerini yansıtan bir ayna özelliğinde olduğu da görülmektedir (Onur, Çelen, Çok, Artar ve Sener-Demir, 1997). Türk toplumlarında da çocuk oyunları, toplumun özelliklerini ve dünya görüşünü temsil etmektedir (Kaya, 2009). And'a göre geçmişte oyun sözcüğünün şaman ve şaman törenlerinin büyüleyici unsurlarına verilen bir adlandırmadır (And, 2003). Türk topluluklarında çocukların oynadığı oyunları yazan en eski kaynak ise Kaşgarlı Mahmut'un yazdığı Divanı Lugat-it Turk eseridir (Akyüz, 2014; Batur \& Beştaş, 2011). Ayrıca Türklerin oyunlarına Dede Korkut hikâyelerinde ve Evliya Çelebinin Seyahatnamesinde de rastlanmaktadır (Megep, 2007).

İnsan var olduğundan bu yana var olduğu düşünülen oyunlar (Özden Gürbüz, 2016), toplumların tarih, gelenek, inanç, edebiyat gibi kültürel zenginliklerini taşıyan bir parçasıdır (Özhan, 1997) ve toplumları tanımayı sağlayan pencere açmaktadır (Cengiz, 1997). Dolaysıyla kültürel oyunları bilen ve oynayan çocuklar, millî bir kimlik kazanmaya başlayacaktır (Bay, Turan, Bay, 2015; Fırat, 2013; Başal, 2010). Aynı oyunu oynayan çocuklar, ortak yaşantıya sahip olarak toplumlar adına ülkü birliğini oluşturmaktadır (Gökşen, 2014). Bu bağlamda oyunlar, geniş bir coğrafyada hüküm süren Türk ve komşu toplulukların kültür birliğini sağlayan en önemli unsurlardan biridir (Bay, Turan, Bay, 2015). Bu birlikteliğin devamlılığının sağlanması geçmiş ile gelecek arasında köprü görevi gören oyunların gelecek nesillere aktarılmasıyla mümkündür (Fırat, 2013; Oksal, 2004). Bu nedenle UNESCO, geleneksel çocuk oyunlarına "somut olmayan kültürel miras" içinde yer vermiş ve bu oyunların korunması gerektiğini belirtmiştir. (Girmen, 2012; Toksoy, 2010).

Günümüzde sınırsız modern oyuncak ve oyun sunulan çocuklar tüketim unsuru olarak görülmüş, teknolojik araçların kullanımıyla çocukların oyun dünyası düzeltilmesi güç değişikliklere maruz kalmıştır (Toksoy, 2010). Toplumların değişen yaşamlarıyla birlikte kültürel miras olan oyunlar (Öz Pektaş, 2017), artık önemini yitirmeye ve unutulmaya başlanmıştır (Arslan, 2017; Öz Pektaş, 2017; Özden Gürbüz, 2016; Tören, 2011; Toksoy, 2010; Esen, 2008; Artar, Onur ve Çelen, 2004). Toplumların kimliğini oluşturan oyunların günümüzde neden oynanmadığının sorgulanması (Arslan, 2017) ve çocuk oyunlarının kayıt altına alınarak (Artar, Onur ve Çelen, 
2004) korunması sağlanmalıdır (Özden Gürbüz, 2016). Oyunların tarihsel ve sosyokültürel unsurlar çerçevesinde incelenmesi ve kültürel aktarımdaki süreklilik ve kopuşun belirlenmesi önemlidir (Rossie, 2005). Bu bağlamda geçmişte oynanan oyunların, oyuncakların ve özelliklerinin belirlenmesi (Arslan, 2017), Türk ve komşu topluluklar olarak geniş bir coğrafya üzerinde araştırma yapılarak kültürel mirasımızın korunması gerekmektedir (Bay, Turan, Bay, 2015). Bu önem ve gerekliliklerden yola çıkılarak kültürel mirasımız olan oyunlarımızın unutulmaması amacıyla yapılan bu araştırmanın, kültürel genlerimizi keşfetme yolculuğunun bir parçası olacağ düşünülmektedir.

\section{Araştırmanın Amacı}

Araştırmanın amacı, Türk ve komşu topluluklarda geçmişten günümüze oynanan oyunların ortaya konulmasıdır. Bu genel amaç doğrultusunda aşağıdaki araştırma soruları belirlenmiştir.

Türk ve komşu topluluklarda;

- Geçmişte oynanan oyunlar nelerdir?

- Bu oyunların özellikleri nelerdir?

- Bu oyunların nasıl öğrenildiğine yönelik görüşler nelerdir?

- Bu oyunların günümüzde hangilerinin unutulduğuna yönelik görüşler nelerdir?

- Bu oyunların unutulmasını önlemeye yönelik görüşler nelerdir?

\section{Yöntem}

Araştırmanın bu bölümünde; araştırmanın modeli, çalışma grubu, veri toplama araçları, verilerin toplanması ve verilerin analizine ilişkin bilgiler yer almaktadır.

\subsection{Araştırma Modeli}

Türk ve komşu topluluklarda geçmişte oynanan oyunların ortaya konulması amacıyla yapılan araştırmada, nitel araştırma modeli kullanılmıştır. Nitel araştırma, araştırmaya katılan kişilerin bakış açılarıyla olgu, olay, norm ve değerleri inceleyen bir modeldir (Işıktekiner ve Altun, 2011; Ekiz, 2009). Gözlem, görüşme veya doküman analizi yöntemleri kullanılan nitel araştırmalarda, olaylar bütüncül olarak doğal ortamında verilmeye çalışılmaktadır (Yıldırım ve Şimşek, 2013). Araştırmada kültürel değerlerin bir unsuru olan oyunlar, Türk ve komşu toplulukların doğal ortamlarında nitel araştırma yöntemlerinden yarı yapılandırılmış görüşme yöntemi kullanılarak, bütüncül bir şekilde ortaya konulmaya çalışılmıştır.

\section{Çalışma Gurubu}

Türk Dünyası Çocuk Oyun ve Oyuncakları Projesi (TÜDÇOOP) kapsamında 20 ülke/bölge (Kazakistan, Kırgızistan, Tacikistan, Ozbekistan, Türkmenistan, Afganistan, Moğolistan, Uygur, Tuva, Hakasya, Altay, Yakutistan, Azerbaycan, Dağıstan/Nogaylar, Kabardey-Balkar, KaraçayÇerkes, Çuvaşistan, Tataristan, Başkurdistan ve Kuzey Kıbrıs Türk Cumhuriyeti) belirlenmiştir. Belirlenen bu bölgelerden Uygur Özerk Bölgesine gidilmiş, fakat görüşme gerçekleştirilememiştir. Türkmenistan'a vize alınamamas1, Afganistan'a ise güvenlik sorunu olması sebebiyle gidilememiştir. Bu nedenle araştırma 17 ülke/bölge ile sınırlı kalmıştır.

Aşağıdaki tabloda araştırma yapılan ülkelerde verilerin toplandığı il, ilçe, köy ve okul sayıları verilmiştir. 
Tablo 1: Saha Araştırmasının Yapıldığı İl, İlçe, Köy ve Okul Sayıları

\begin{tabular}{lcccc}
\hline \multicolumn{1}{c}{ Ülkeler } & Şehir & İlçe & Köy & Okul \\
\hline Kazakistan & 2 & 2 & 1 & 2 \\
Kirgızistan & 1 & 0 & 4 & 1 \\
Tacikistan & 3 & 1 & 2 & 2 \\
Özbekistan & 7 & 3 & 4 & 0 \\
Moğolistan & 1 & 1 & 2 & 1 \\
Tuva & 1 & 0 & 1 & 1 \\
Hakasya & 1 & 1 & 3 & 0 \\
Altay & 1 & 0 & 1 & 1 \\
Yakutistan & 1 & 0 & 1 & 3 \\
Azerbaycan & 1 & 2 & 2 & 2 \\
Dağıstan & 2 & 1 & 2 & 2 \\
Kabardey-Balkar & 2 & 0 & 3 & 3 \\
Karaçay-Çerkes & 2 & 0 & 1 & 3 \\
Tataristan & 1 & 0 & 4 & 6 \\
Başkurdistan & 3 & 0 & 7 & 2 \\
Çuvaşistan & 1 & 1 & 2 & 2 \\
KKTC & 3 & 0 & 2 & $\mathbf{3 2}$ \\
\hline Toplam & $\mathbf{3 3}$ & $\mathbf{1 2}$ & $\mathbf{4 2}$ & \\
\hline
\end{tabular}

Tablo 1: İncelendiğinde saha araştırmasının yapıldığı 17 ülke/bölgede toplam 33 şehir, 12 ilçe, 42 köy ve 32 okul ziyareti yapılmıș ve veriler toplanmıștır. Araştırmada, araștırma sorularına taraf olabilecek kişilerin çeşitliliğini maksimum derecede yansıtmak amacıyla (McMillan ve Schumacher, 2006; Yıldırım ve Şimşek, 2013) amaçlı örnekleme yöntemlerinden maksimum çeşitlilik örneklemesi kullanılmıştır. Maksimum çeşitlilik örneklemesinde amaç genelleme yapmak değil, çeşitlilik gösteren olgular arasında benzerlik olup olmadığ 1 ve bu çeşitlilik doğrultusunda araştırma sorularının farklı boyutlarını ortaya koyabilmektir (Kaleli Yılmaz, 2012). Bu nedenle, farklı özelliklere sahip katılımcılar belirlenmiştir. Katılımcılar, ülkelerinin baş harflerine göre kodlanmıştır (Kazakistan: Kz, Kırgızistan: Kr, Tacikistan: Tc, Ozbekistan: Öz, Moğolistan: Mğ, Tuva: Tv, Hakasya: Hk, Altay: Al, Yakutistan: Yk, Azerbaycan: Az, Dă̆ıstan: D̆g, Balkar: Bl, Karaçay: Kç, Çuvaşistan: Çv, Tataristan: Tt, Başkurdistan: Bş, Kuzey Kıbrıs Türk Cumhuriyeti: KKTC). Katılımcıların bilgileri aşağıdaki tabloda verilmiştir.

Tablo 2: Kat1lımc1ların Özellikleri

\begin{tabular}{llll}
\hline Katılımcı Özellikleri & & N & $\%$ \\
\hline Cinsiyet & Kadın & 54 & 54 \\
& Erkek & 46 & 46 \\
\hline Yaş & 40-60 yaş & 61 & 61 \\
& 60 yaş üstü & 39 & 39 \\
\hline \multirow{2}{*}{ Meslek } & Öğretmen & 35 & 35 \\
& Araştırmacı Yazar & 6 & 6 \\
& Diğer & 59 & 59 \\
\hline
\end{tabular}

Araştırmada 54 kadın 46 erkek olmak üzere toplam 100 katılımcı yer almıştır. $\mathrm{Bu}$ katılımcılardan 39'u 60 yaş üstü, 35'i ise öğretmendir.

\section{Verilerin Toplanması ve Analizi}

Veriler toplanmaya başlanmadan önce belirlenen ülkelerde bulunan üniversitelerin ilgili bölümleri ve araştırmacılarla görüşülmüş, TIKKA (Türk İşbirliği ve Koordinasyon Ajansı) işbirliğinde güzergâhlar belirlenmiştir. Veriler iki yılda, her yıl 3 aylık yaz dönemi olmak üzere yaklaşık 6 aylık bir süre içinde toplanmıştır. Ülkelere göre değişen aşırı sıcak veya soğuk ikilim şartlarında yapılan araştırmada, çoğunlukla kara yolu kullanılmış ve kırsal kesimlerde çok zorlu yol 
güzergâhlarında gidilmiştir. KKTC ve Azerbaycan dışındaki diğer ülkelerde tercüman desteği alınmıştır.

Araştırmada yarı yapılandırılmış görüşme yöntemi kullanılmıştır. Görüşme yöntemi, duygular, düşünceler ve geçmiş yaşantılar gibi gözlenemeyen durumlar hakkında bilgi edinmek için kullanışlı bir yöntemdir (Glesne, 2015). Nitel araştırmalarda araştırmanın geçerliliğini sağlayan katılımcıların gönüllü katılımı (Yıldırım ve Şimşek, 2013) dikkate alınarak geçmişte oynanan oyunlar üzerine açık uçlu sorular sorularak görüşme yapılmıştır. Görüşme sorularının amaca uygunluğunu ve anlaşılırlığını kontrol etmek için, üç alan uzmanından görüş alınmış ve görüşme soruları düzenlenmiştir. Görüşmeler yüz yüze yapılmış ve görüşme sırasında video kaydı alınmıştır. Görüşmeler yaklaşık 15-45 dakika sürmüştür.

Elde edilen verilerin analizinde betimsel ve içerik analizi kullanılmıştır. Görüşmelerden alınan video kayıtları dinlenmiş, katılımcıların görüşme sorularına verdikleri cevaplar, kâ̆̆ıtlara aktarılarak doküman haline getirilmiştir. Görüşme dökümleri, betimsel olarak analiz edilerek verilerin hangi kategoriler altında düzenleneceği ve sunulacağına yönelik çerçeve belirlenmiştir. Betimsel analiz yapılan verilerin daha derinlemesine incelemesi, kavram ve kategorilerin belirlemesi için içerik analizi yapılmıştır. İçerik analizi ile veriler araştırmacılar tarafından ayrı ayrı kodlanmış ve temalar oluşturulmuştur. Ortaya çıkan temaların frekans ve yüzdeleri hesaplanmıştır. Bazı katılımcılar açık uçlu soruları yanıtlarken aynı cevap içerisinde birden fazla temaya yönelik görüş belirttiğinden, frekansların toplamı katılımcı sayısından farklı olabilmektedir.

Araştırmacılar tarafindan görüşme dokümanı üzerinde ayrı ayrı yapılan kodlamaların uyumuna bakılmış, kodlama güvenirliği, [Görüş Birliği / (Görüş Birliği + Görüş Ayrılığı)] (Miles ve Huberman, 1994) formülüne göre hesaplanmış ve 0,92 yüksek güvenirlik katsayısı değeri bulunmuştur. Kodlamaların uyuşamadığı kodlamalara tekrar bakılmış ve kodlar üzerinde uzlaşma sağlanmıştır.

\section{Bulgular}

Yapılan araştırma sonucunda elde edilen bulgular araştırma soruları doğrultusunda bu bölümde verilmiştir. nelerdir?

Araştırmanın birinci sorusu: Türk ve komşu topluluklarda geçmişte oynanan oyunlar

Görüşmelerde katılımcılara çocukluklarında hangi oyunları oynadıkları sorulmuş ve elde edilen veriler aşă̆ıdaki tabloda verilmiştir.

Tablo 3: Türk ve Komşu Topluluklarda Geçmişte Oynanan Oyunlar

\begin{tabular}{|c|c|c|}
\hline Ülkeler & $\mathbf{N}$ & Görüşmelerde Söylenen Oyunlar \\
\hline Kazakistan & 18 & $\begin{array}{l}\text { Ak törek gök törek (Bizden size kim gerek), Aşık beygel (Aşıkla oynanan at yarış1 } \\
\text { oyunu), Aşık atuv (aşık atma), Aşık (Aşık vurdurma), Aşık çıarma, Kol küresi (Bilek } \\
\text { güreşi), Kim birinci (Mendil kapmaca), Arkan tartmayı (Halat çekme), Kız kovu (Kız } \\
\text { kovalama), Yüzük salu (Yüzük saklama), Şeşe (Kuyruk yakalama), Sokur teke (Körebe), } \\
\text { Aşı (Beş taş), Otluk, İnguluv, Kimdir o, Uçtu uçtu, İp }\end{array}$ \\
\hline Kırgizistan & 20 & $\begin{array}{l}\text { Top taş (beş taş), Göz tanbay (Körebe), Şakek salmayı (Yüzük saklama), Kaçmay top } \\
\text { (Yakan top), Arkan tartmayı (Halat çekme), Dokuz Kargoo (Mangala), Yoluk tastamayı } \\
\text { (Yağ satarım), Ak törek gök törek (Bizden size kim gerek), Aşı (aşık çıarma), } \\
\text { Akçölmöt, Atkopça, Bebekler (Evcilik), Bulturmuş oyunları, Çüllük (Çelik Çomak), } \\
\text { Gökbörü, Hasır, Kız kovu, Kurçak, Selkincik, Kedi fare }\end{array}$ \\
\hline Tacikistan & 20 & $\begin{array}{l}\text { Sançil (Beş taş), İlig dangal (Çelik çomak), Rulmaçya potai (Yağ satarım), Lamka } \\
\text { (Ayakta kurşun dökülmüş deri sektirme), Çarmagz (Aşık çıkarma), Dülço bozi horok } \\
\text { bozi (Eşek oyunu), Kuşbak basagani (Orta sıçan), Jon Girek (Yakan top), Sefador siyador } \\
\text { (Bizden size kim gerek), Rusţ̧avakan (Saklambaç), Cormagz (Aşı vurdurma), } \\
\text { Bamkoşak (Halat çekme), Cormagz (Aşık), Dom dom (El çırpma oyunu), Duhtaraki zebo }\end{array}$ \\
\hline
\end{tabular}


(Cici kız), Haskunak (Zıplama), Karguşak, Mo poy mazenem (Tekerlemeli oyun), Rubai hobideh (Kuş kondu), Evcilik

Özbekistan 19 Beş ataş (Beş taş), Göz bağlama (Körebe), Lale lale (Kuyruk yakalama), Ördek avcı (Yakan top), Çakallak (Yerden alma), Ak törek gök törek (Bizden size kim gerek), Ayrı (Sapan), Cik (Uzun eşek), Aşık, Çüllük (Çelik Çomak), Döndürek (Topaç), Kuvvet sınama (Bilek güreşi), Kazlarım, Eşek oyunu, Par (Ayakta kurşun dökülmüş deri sektirme), Gül ve taş, İp, Mak Mak (Sek Sek), Yeşil Topalak (Saklambaç)

Moğolistan 18 Güreş, Kulaktan kulağa, Arkan tartu (Halat çekme), Teuk (Ayakta kurşun dökülmüş deri sektirme), Mori uraduulah (Aşıkla oynanan at yarışı oyunu), Shagai nyaslah (Aşık vurdurma), Shagai shuuren (Aşık toplama), Shagai taaltsah (Tahmin etme), Arkadaş, Şıt sitav (Yağ satarım), Ak törek gök törek (Bizden size kim gerek), Dokuz kumalak (Mangala), Mendil kapmaca, Ahşap yapboz, Alag melhi, Bugi niluulek, Dugi daği, Kedifare

Yakutistan 21 Habsaga (Güreş), Hamıska (Beş taş), Kara simse (Körebe), Kruussa uanna khatay (Kuyruk yakalama), Yüzük saklama, Kulaktan kulağa, Atlasava zhanna (Yakan top), Görçe (Topaç), Oyban nohuna (Yerden alma), At süh (Kız kovalama), Kabılık (El üstünde yakalama), Tutum ergir, Tounçuk, Jipto, Nartı (Engel atlama), Tıksa, Ketek tardihi (Kafa çekme), İnek yarışı, İğne sap (İğne iplik), At sürühü, Ağaç etrafinda dönme

Tuva $\quad 15$ Karak bağlan (Körebe), Aksak kaday (Kuyruk yakalama), Bilzek çazırağı (Yüzük saklama), Telefon (Kulaktan kulağa), Aşık, Güreş, Tevek (Ayakta kurşun dökülmüş deri sektirme), At çarızı (Aşıkla oynanan at yarışı oyunu), Atıp oynarı (Aşık vurdurma), Karara (Aşık toplama), Bodovajga (Tahmin etme), Aram şim şim (Arkadaş), Çaştınıp Onar (Saklambaç), Sek sek, El üstünde yakalama

\begin{tabular}{|c|c|c|}
\hline Hakasya & 7 & $\begin{array}{l}\text { At yarış1 (Aşıkla oynanan at yarışı oyunu), Aşık vurdurma, Bilek güreşi, Bezden Kukla, } \\
\text { Galistal, Naluptu, Pre Atgi (Körebe) }\end{array}$ \\
\hline Altay & 10 & $\begin{array}{l}\text { Böğrü ve ursallık (Kuyruk yakalama), Sırgay jagırış (Yüzük saklama), Ançıle oyun } \\
\text { (Yakan top), Armakjı dartgış (Halat çekme), Tevek (Ayakta kurşun dökülmüş deri } \\
\text { sektirme), Dokuz kumalak (Mangala), Küpe yarışı, Şatra, Soguş, Taş oyunu }\end{array}$ \\
\hline Azerbaycan & 32 & $\begin{array}{l}\text { Dire dövme (Kemer), Elim sende, Şeker buram, İ̆ge iğne (Ayak çekme), Fincan fincan } \\
\text { (Yüzük saklama), Kulaktan kulağa, Ortada kaldı (Yakan top), Kendir (Halat çekme), } \\
\text { Çileme (Ayakta kurşun dökülmüş deri sektirme), Desmal desmal (Yağ satarım), Kazlar } \\
\text { kazlar, Goz goz (Aşı atma), İp, Sapan, Beş taş, Aşık, Benövşe benövşe (Bizden size } \\
\text { kim gerek), Çiling ağaç (Çelik çomak), Düdük, Ebe mene zu, Enzeli (Birdirbir), } \\
\text { Gizlembaç (Saklambaç), Göz bağlama (Körebe), Kabarzum, Mere mere, Pergale, Pul pul, } \\
\text { Şakuldak, Top top, Tut tut, Meteni, Yedi ağaç }\end{array}$ \\
\hline Dağıstan & 41 & $\begin{array}{l}\text { Ak törek gök törek (Bizden size kim gerek), Aşık çıkarma, Aşık vurdurma, Aşık atma, } \\
\text { Art anay (Düğ̈um), Zincir, Ateşin üstünden atlama, Beş taş, Cıncırak döndürme (Topaç), } \\
\text { Çanak çerbedi, Çelik çomak, Çı̆gıl, Duk duk duk dep, Eşek müyüş (Uzun eşek), Göz } \\
\text { bağlama (Körebe), İp oyunu, İpin üstünden atlama (İp atlama), Kaçı tutup } \\
\text { (Kovalambaç), Kazık, Kızılbayrak, Klas, Lenka (Ayakta kurşun dökülmüş deri } \\
\text { sektirme), Maskara maskara, Ok-yay, Para döndürme, Samahat, Şişgan bişik (Kedi fare), } \\
\text { Topu atarak tekerleme söylemek, Uçurtma, Uyden uy, Kol yağluk (Yağ satarım), Yaşılıp } \\
\text { gumulup (saklambaç), Yumurta tokuşturma, Yumurtga (Yumurta taşıma), Yüzük } \\
\text { saklama, Bebek (Evcilik), Gökte ne var, Aylan gavur (Kuyruk yakalama), Dört taş beş } \\
\text { taş, Ulavlarım hav hav, Dokuz kiremit }\end{array}$ \\
\hline $\begin{array}{l}\text { Kabardey } \\
\text { Balkar }\end{array}$ & 24 & $\begin{array}{l}\text { Ağaç börü, Aşık atma, Kalgan (Beş taş), Bohuluş, Çüyke (Çelik çomak), Eşek (Birdirbir), } \\
\text { Evcilik, Gökte ne var, Hoynuk (Topaç), İp, Kim gerek, Kol taş, Orta top (Yakan top), Sek } \\
\text { sek, Taban dövüş, Arkan tartgan (Halat çekme), Yüzük saklama, Cu cu cavala } \\
\text { (Gidıklama), Tartuşu (Bezirganbaşı), Obur (Kovalamaca), Lenka (Ayakta kurşun } \\
\text { dökülmüş deri sektirme), Börk atuv (Yağ satarım), Aylan alan bilek, Sopayla taş atma. }\end{array}$ \\
\hline Karaçay & 29 & $\begin{array}{l}\text { Iz dız (sek sek), Iz dız (Taş sürme), Ay melek (Kim gerek), Aşık atma, Aşık çıkarma, } \\
\text { Aşık vurdurma, Beş taş, Birbirimizi ıslatırdık, Cüzük oyun (Yüzük saklama), Çıkışkıp, } \\
\text { Çörkük, Güreş, Hoynuk (Topaç), Kamçı sadak (Kamçı çekme), Kol taş, Orta top (Yakan } \\
\text { top), Regetga (Sapan), Sikan dirbek (Bilek güreşi), Suda çöple kayık yarıştırma, Suda taş } \\
\text { sektirme, Taş atma, Teke, Amma cukka, Ayak sıkan dirbek, İt almaz, Kabırga top, Kolun }\end{array}$ \\
\hline
\end{tabular}




\begin{tabular}{|c|c|c|}
\hline & & burgan, Pila top, Tayak cisir \\
\hline Başkurdistan & 26 & $\begin{array}{l}\text { Kayış (Kemer), Sekiz kapak (Dokuz kiremit), Naza (Köprü), On iki sopa, Ak törek gök } \\
\text { törek (Bizden size kim gerek), Kazlar kazlar, Biz biz idik (Ağzını yum), Ak kalas (Şeker } \\
\text { buram), Boya, Köşe kapmaca, Alırım kuş (Kuyruk yakalama), Çuval yarışı, Hepelek } \\
\text { (Körebe), Kız kovalama, Kelek, Saklambaç, Sek sek, Uçtu uçtu, Yakan top, Yeşilim } \\
\text { yağlık (Yağ satarım), Yumurta taşıma, Öküz yüzük (Yüzük saklama), Bıtır butga bişen } \\
\text { (Ağzını yum), Hukmatup, Kırk taş, Küldürgüz }\end{array}$ \\
\hline Tataristan & 33 & $\begin{array}{l}\text { Mesik sıçkan (Kedi fare), Şuma ördek şuma kaz (Köprü), Biz biz idik (Ağzını yum), } \\
\text { Boya, Semaver, Pisi pisi nindi dişi (Renk bulma), Çuval yarışı, Yumurtga (Yumurta } \\
\text { taşıma), Yılan (Kuyruk yakalama), Aşık, Beş taş, Buzlu oyunu, Fırıldak (Düğme } \\
\text { çevirme), Gırli oyunu, Göz bağlama (Körebe), İp, Kazlar kazlar, Kız kovalama, Koşa } \\
\text { koşa (Saklambaç), Kovalamaca, Kaburgalık (Bizden size kim gerek), Yurt sütiş } \\
\text { (Düğüm), Sek sek, Şavata (Yakan top), Şişe çevirme, Tayak (Çelik çomak), Telefon } \\
\text { (Kulaktan kulağa), Vatık, Yağlık (Yağ satarım), Yüzük salış (Yüzük saklama), On iki } \\
\text { tayak (On iki sopa), Kurşak alış, Tübetey (Şapka) }\end{array}$ \\
\hline Çuvaşistan & 22 & $\begin{array}{l}\text { Kayış (Kemer), Kazaki (Kovalamaca), Vıyı kardi (Kedi fare), Hur gaikse (Bazirganbaşı), } \\
\text { İşgaydirizimle (Semaver), Alırım kuş (Kuyruk yakalama), Beş taş, Çuçu (Salıncak), Göz } \\
\text { bağlama (Körebe), Oy dimeo (Kim gerek), Köşe kapmaca, Lapta, Mungun oyunu, Orta } \\
\text { Top (Yakan top), Sek sek, Şımarda kusturmalla (Yumurta Yarıştırma), Telefon (Kulaktan } \\
\text { kulağa), Tuflilya (Yağ satarım), Puşmak (Yüzük saklama), Uzun eşek, Muci, Yuvancı }\end{array}$ \\
\hline KKTC & 41 & $\begin{array}{l}\text { Dokuz kiremit, Gavrıncık (Gıdıklama), Kapıcıbaşı (Bezirganbaşı), Sek sek, Renk } \\
\text { söyleme, Çuval yarışı, Yumurta taşıma, Tahta tahta ben var (Ayak çekme), Körebe, } \\
\text { Fincan oyunu (Yüzük saklama), Beş taş, Saklambaç, Yağ satarım, Alaydan malaydan } \\
\text { (Kim gerek), Adam asmaca, Ağaç dönmesi, Andrez oyunu, Lingili (Çelik çomak), } \\
\text { Üçgen (Aşı çıkarma), Pirilli (Aşık atma), Parmakta ip, Çift deli linda, Dama, Evcilik, } \\
\text { Harp oyunu, Hırsız polis (Kağıt Oyunu), İp atlama, İsim söyleme(Ritim İle), Kara kedi } \\
\text { oyunu (Kedi-fare oyunu), Köşe kapmaca, Lades oyunu, Okçuluk, Plaka (Taş sürme), } \\
\text { Sandalye kapmaca, suda taş sektirme, Uçurtma, Zangalak savaşı(Sapan), Zincirleme, İki } \\
\text { parmakta ip çözme, Uzun eşek, Tahmin etme }\end{array}$ \\
\hline
\end{tabular}

Tablo 3: İncelendiğinde, yapılan görüşmelerde 396 kültürel oyunun katılımcılar tarafından söylendiği görülmektedir. Bu oyunlardan 112 oyunun sadece bir bölgede olduğu, geriye kalan beş taş ve kim gerek gibi 284 oyunun diğer ülke/bölgelerde de tekrarlandığı görülmüştür. Tablo 3. farklı oyun çeşidi açısından incelendiğinde, 173 farklı oyunun görüşmelerde ifade edildiği görülmektedir.

KKTC dışındaki ülkelerde 60 yaş üzerindeki katılımcılarla yapılan görüşmelerde, 2. Dünya Savaşının önemli bir etkisi olduğu görülmüş ve çocuklukları savaş dönemine gelen katılımcıların çok azı oyun oynadığını söyleyebilmiştir. Karaçay ve Balkar'da yaşayan Türk topluluklarının sürgün gönderildiği o dönemde, yokluk ve sefalet nedeniyle katılımcılar çocukluklarında ailelerine yardım etmek zorunda olduklarını; fakat tarlaya ya da hayvan otlatmaya gittiklerinde buldukları her firsatta oyunlar oynadıklarını ifade etmişlerdir. Geçmişte oynanan oyunlar üzerindeki bir diğer etken ise Sovyetler Birliğinin dağılmasının ardından Azerbaycan, Kazakistan, Kırgızistan, Özbekistan ve Tacikistan'ın bağımsızlıklarını kazanmalarıdır. Bununla birlikte Tataristan, Başkurtistan, Yakutistan (Saha), Çuvaşistan, Altay, Hakasya, Tuva, Karaçay-Çerkes, KabardinBalkar, Dağıstan gibi Türk topluluklarının özerk cumhuriyet statüsünü kazanmalarının etkisi görülmektedir. Katılımcılar bağımsız olmadan önce kültürlerini koruyamadıklarını, bağımsızlıktan sonra kültürel değerlerini tekrar hatırlamaya ve korumaya çalıştıklarını ifade ettikleri görülmüştür. KKTC'de ise 100 yıl süren İngiltere yönetimi döneminde katılımcıların oyunlarını yeterince koruyamadıklarını belirttikleri görülmüştür. Geçmişte oynanan kültürel oyunların, oyunlar üzerinde derleme çalışmaları yapan araştırmacı yazar ve öğretmen katılımcılar tarafindan daha iyi hatırlandığı gözlenmiştir. Katılımcıların cevaplarından bazıları aşağıda verilmiştir: 
Kz: "Gençken ak törek, sokur teke, otluk, kız kovu, inguluv, aşık oyununu oynuyorduk ama yine baskı altındaydık. Bağımsız olduktan sonra nevruzlarda oyunlar oynadık."

Kr: "Dokuz Kargoo (Mangala), Ak törek gök törek (Bizden size kim gerek), Aşık (aşık çıkarma) oynardık. Baskı altında kaldığımız için manas eposunu bile bize okutmuyorladı. Dilimizi de dinimizi de yeni öğreniyoruz. Bizim soyadlarımızı değiştirdiler. Dersler Rusçaydı yavaş yavaş Kirgizca oluyor."

Tc: "Eskiden İlig dangal (Çelik çomak), Lamka (Ayakta kurşun dökülmüş deri sektirme) oynardık. Yemeğimizi yer, geri kalan zamanda hep oyun oynardık. Büyüklerimiz oyunlarımıza katılmazdı, kendimiz yaşıtlarımızla oynardık. Oyuncakları kendimiz yapardık. Şimdiki çocuklar kültürel oyunlar oynamıor."

Al: "Oyun olmadan yaşadım. Çocukluğum savaş zamanlarında geçti. İlk zamanlarda oynanan oyun sayısı fazlaydı ancak zor zamanlar oldu. 15 yaşına kadar koyun otlattım, çobanlık yaptım. O zaman çayırlarda firsat buldukça aşık oynardım. Daha sonra hayatım savaş zamanlarında geçti."

Az: "Köyde büyüdüğümüz için saklambaç, gizlenbaç da diyoruz. Saklanmak daha kolay. Bir de bizim orada şey var, çiling ağaç. Büyük bir sopa var. Tabi o biraz daha tehlikeli mesela onu biz burada oynatmıyoruz. Sert bir vuruş, karşı tarafta biri onu tutmaya çalışır, tekrar geri firlatmaya çalışır. Tehlikeli bir oyun. Bunu oynardık yani, yerleşim buna müsaitti."

Çv: "Köyler arasında gençler birbirlerini ziyaret ederlerdi. Karşı köyden gelen genç erkekler dans etme, şarkı söyleme gibi becerilerinin göstermeleri köyün gençleri tarafından teste tabi tutulur. Bunu beceremeyen misafir olan genç köyüne geri gönderilir. İçki içen ve sarhoş olarak ziyarete gelen genç köye dahi alınmazdı. Beş taş oyununda taşların çok yuvarlak ve pürüzsüz olmasına dikkat ederdik. Sek sek oyununda çizgilere hiç basmadan oynayanlar için iyi dansçı olacak derdik."

Dğ: “Aşık oynardık. Kovalambaç oynardık. Klas oyunu (taş sürdürme), kazuk oynardık. Kazığı vururduk, ilk sırayı yıkardık, kazıkları yıkar, toplar, götürür, yakardık. Ak törek gök törek oynardık. Taşlarla beştaş oynardık, parmakta ip oyunu oynardık."

"Birinci olarak yumurtga oynardık. Topu havaya atıp tekerleme söylerdik. Yumurtga kimde, yumurtga kimde diyerek topla vurmaya çalıșırdık. Bașka oyunlardan lenka oynardık. Koyun derisine kurşun dökülürdü, oyunu onunla oynardık. Küçükken oynadığımız oyunlardan başka çığıl (tekerlek) oynardık. Açıp tutup oynardık, şişgan bişik (kedi fare ) oynardık. El ele tutuşup daire olurduk. Bir kişi şişgan diğeri bişik olurdu. Bişik dairenin dışında, şişgan içinde olurdu. Bişik, şişganı yakalamaya çalışırdı. Dairedekilerde onu engellemeye çalışırdı. Ak törek gök törek oynard1k."

"Kazık oyunu oynardık. Kazığı yere saplardık. Başkası da onu yıkmaya çalışırdı. Yaşılıp gumulup (saklambaç) oynardık. Birisi gözlerini kapatırdı yumulurdu. Diğerleri saklanırdı. O da bulmaya çalışırdı. Diğerleri gelip vururdu."

Kç: . "Ben çocukken hoynuk, aşık, taş atma cüzük oyun, çörkük, teke, taşla vurup oynardık oyunlarını oynardım. Kazakistan'a sürgün edildim. Orada da aşı oyunları oynanırdı."

Tt: "Beş taş, yüzük salış, ip, şavata(orta top), göz bağlama, tayak (çelik çomak), şişe çevirme oyunlarını çok oynardık."

KKTC: "Beş taş, Saklambaç, İp atlardık, bisiklet sürerdik. Beş taşın aşamaları vardı. Köprü yapardık, birli ikili taşları alırdık. Sek sek oynardık. Taş sürme oynardık, plaka derdik bu oyuna. Toplarla da oynardık ama benim en çok sevdiğim ip atlamaydı. Okuldan eve gelince ipimi alır ip 
atlardım. Koşarak oynardık, durarak ip atlardık. Körebe oynardık, yağ satarım bal satarım oynardım. Elimize ip geçirip oynardık."

Araştırmanın ikinci sorusu: Türk ve komşu topluluklarda geçmişte oynanan oyunların özellikleri nelerdir?

Görüşmelerde katılımcıların çocukluklarında oynadıkları oyunların nerede oynandığı, ne kadar süreyle oynandığı, bu oyunları oynamak için hangi oyuncakları kullandıkları sorulmuştur. Elde edilen veriler Tablo 4'de verilmiştir.

Tablo 4: Geçmişte Oynanan Oyunların Nerede ve Ne Kadar Süre Oynandığı

\begin{tabular}{cccccc}
\hline & \multicolumn{2}{c}{ NEREDE OYNANDIĞI } & \multicolumn{3}{c}{ KAÇ SAAT OYNANDIĞI } \\
\cline { 2 - 6 } & Diş Mekan & $\begin{array}{c}\text { İç veya Diş } \\
\text { Mekan }\end{array}$ & $1-3 \mathrm{~s}$. & $3-5 \mathrm{~s}$. & DAHA ÇOK \\
& $\mathrm{N}$ & $\mathrm{N}$ & $\mathrm{N}$ & $\mathrm{N}$ & $\mathrm{N}$ \\
TOPLAM & $\mathbf{8 2}$ & $\mathbf{1 8}$ & $\mathbf{3 0}$ & $\mathbf{2 2}$ & $\mathbf{4 8}$ \\
\hline
\end{tabular}

Tablo 4: incelendiğinde çadırda ve kırsal yaşamın çoğunlukta olduğu geçmişte oynanan oyunların çoğunluğunun dış mekanlarda ve süre sınırlaması olmadan oynandığı görülmektedir.

Görüşmelerde katılımcılar oyunlarda oynadıkları oyuncaklarını kendileri yaptıklarını belirtmiştir. Oyunların oynanmasında kullanılan oyuncakların neler olduğu aşağıdaki tabloda verilmiştir.

Tablo 5: Geçmişte Oynanan Oyunlarda Kullanılan Oyuncaklar

\begin{tabular}{|c|c|}
\hline Ülkeler & Oyunlarda Kullanılan Oyuncaklar \\
\hline KAZAKİSTAN & Așık, Taş, Sopa, Yoluk (mendil), Yüzük, Deri, İp, Kamçı \\
\hline KIRGIZISTAN & Aşık, Taş, Sopa, Yoluk (mendil), Kamçı, Yüzük, Deri, İp \\
\hline TACÍKISTAN & Küçük yastıklar, Bebek, Yüzük, Mendil, Ağaç sopalar, Așık, Ceviz \\
\hline ÖZBEKİSTAN & $\begin{array}{l}\text { Velesibir, Aşık, Trak, Hoçka, Pilesirin, Taş, Bez, Tahta, Bebek, Ağaç, Topaç, Deri, } \\
\text { Ağaç sopalar }\end{array}$ \\
\hline MOĞOLISTAN & Așık, Kemik, Taş, Kumaştan bebek, Halat, Deri, Mendil, İp \\
\hline TUVA & Ağaçtan düdük, Ok-yay, Taş, Yüzük, Deri, Așık \\
\hline HAKASYA & Bez, Aşık, Mendil \\
\hline ALTAY & Yüzük, Deri, Kemik, Halat \\
\hline YAKUTISTAN & Tahta çubuk, Aşık, Taş, Tahta, Yüzük, Topaç, Sopa \\
\hline AZERBAYCAN & İp, Taş, Sapan, Tahta, Kabarzum, Kırbaç, Pergalle, Düdük, Ceviz \\
\hline DAĞISTAN & Ağaçtan ayakkabı, Kukla, Yaprak, Su tabancası, Ok-yay, Uçurtma, Kaval \\
\hline BALKAR & Koyun yününden top, Taş, Aşı, Yüzük \\
\hline KARAÇAY & İnek derisinden top, Taş, Ağaçtan kayık, Aşık \\
\hline BAŞKURDISTAN & İnek kılından top, Kemikten bebek, Ağaç ve kemiklerden bebek ve araba, Kukla \\
\hline TATARISTAN & Balçıktan bebek, Taş, İp, Düğme, Top, Sopalar, Balık kılçı̆ğı (omurgası) \\
\hline ÇUVAŞiSTAN & Taş, İnek tüyünden top, Sopa, Mendil, Yüzük \\
\hline KKTC & $\begin{array}{l}\text { Bisikletin iç lastiğiyle yapılan top, Kumaş, makara veya değnekten bebek, Taş, } \\
\text { Mendil, Aşık, Sopa, Kağıt-kalem, Sandalye, Misket, Makaradan veya ayakkabı } \\
\text { kutularından araba, Kamış, Kamıştan düdük, Silah, Kuş lastiği, Topaç, Uçurtma, } \\
\text { Hurma dalı ve gazoz kapağından ok-yay, Sapan, İp, Beşik, Halat, Renkli camlardan } \\
\text { tabak }\end{array}$ \\
\hline
\end{tabular}

Aşağıda görüşmelerde verilen cevaplardan bazı örnekler verilmiştir.

Tv: "Ağaçtan düdük yapardık, ok, yay yapardık."

"Aşıklarla oynardık. Aşıkları koyun, inek, geyik, yaban domuzu gibi hayvanların ayaklarından alırdık."

Mğ: "Çocukken dikiş diker, kumaşlarla bebek yapardım. Taşlarla ev yaparak oynardık." 
"Oyunlarımızda oyuncak olarak aşık ve kemik kullandık."

Tc: "Oyuncakları kendimiz yapardık. Küçük yastıklar, bebekler hazırlardık."

"Kalan kumaşlara pamuk koyar annelerimiz bebek yapardı. Onlarla oynardık." yapardım."

Bş: "Oyuncaklarımı kendim yapardım. Topu inek kılından yapar, kemiklerden bebekler

Çv: "İneğin dökülen tüylerinden toplar yapar; onlarla oynardık."

Dğ: "Eskiden oyuncaklar yoktu. Kendi oyuncaklarımızı kendimiz yapardık. Kukla yapardık. Hazır dükkândan alıyorlar. Oyuncak alacak paramız yoktu kendimiz yapardık."

Bl: "Koyun yününden top yapardık."

"Oyuncakları önce kendimiz yapıyorduk. Şimdi hazır. Telefonla oynuyorlar." yapard1k."

Kç: "Oyuncaklarımız inek derisinden olurdu. İnek derisiyle top, taş, ağaçtan kayık, aşık

Tt: "Kızıl balçıktan bebekler yapardık. Balçıktan oyuncaklar yapardık."

KKTC: "Top yapardık, küçük çakıl taşıyla bisikletin iç lastiğiyle sara sara top yapardık. Bebek yapardık, eski kumaşlardan elbise yapar, saç yapardık, boncuktan göz dikerdik.”

"Bebek yapardım, Komşuculuk oynardık. Renkli camları toplar tabak yapardık. "

"Makaralardan arabalar, bebekler yapılırdı, değneklerden haç sekline getirilip bebekler yapılırdı, ayakkabı kutularından araba yapardık, kamışlardan atçılık oynardık."

"Çocukken çok yaratıcı oyuncaklar yapardık. Hurma dalından yay yapar, okun ucuna gazoz kapağı yakar okçuluk oynardık. Oyunda sahtekârlık yapanlara bir daha yaparsan seni almayacağız oyuna derdik ve bu ciddi bir cezaydı. Bu kural çocuk için çok önemliydi çocuk dürüstlüğü öğreniyordu."

Katılımcıların ifadelerinde de görüldüğü gibi geçmişte oynanan oyunlarda çocukların çoğunlukla taş, ağaç, hayvan derisi, tüyü, kemikleri gibi doğal malzemeleri kullandıkları görülmektedir. Doğal malzemelerin yanı sıra gazoz kapağı gibi atık ürünlerinden kullanıldığı ifade edilmiştir.

Araştırmanın üçüncü sorusu: Türk ve komşu topluluklarda geçmişte oynanan oyunların nasıl öğrenildiğine yönelik görüşler nelerdir?

Araştırmada katılımcıların çocukluklarında oynadıkları oyunları arkadaş, ağabey/abla veya anne/babalardan öğrendiklerini ifade ettikleri görülmüştür. Katılımcıların oyunları kimlerden öğrendikleri Tablo 6'da gösterilmiştir.

Tablo 6: Geçmişte Oynanan Oyunların Kimlerden Öğrenildiği

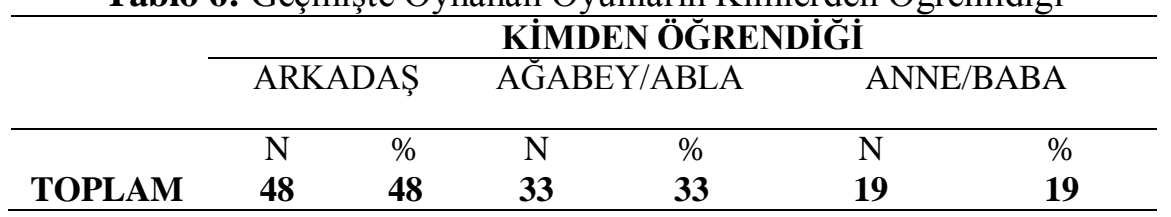

Katılımcılar, oyunları en fazla arkadaşlarından, ikinci sırada ise küçüklükten itibaren oyunlarını gözlemledikleri ağabey ve ablalarından öğrendiklerini ifade etmişlerdir. 
Araştırmanın dördüncü sorusu: Türk ve komşu topluluklarda geçmişte oynanan oyunların günümüzde ne kadarının unutulduğuna yönelik görüşler nelerdir?

Görüşmelerde katılımcılara geçmişte oynanan oyunlardan günümüzde hangilerinin unutulduğunu düşündükleri sorulmuştur. Katılımcılar, bazı oyunların günümüzde çocuklar tarafından oynanmadığını ve bilinmediğini ifade etmiştir. Aşağıda hangi oyunların günümüzde unutulduğuna yönelik görüşlerin yer aldığı Tablo 7'de verilmiştir.

Tablo 7: Günümüzde Unutulduğu Düşünülen Oyunlar

\begin{tabular}{|c|c|c|}
\hline Ülkeler & $\mathbf{N}$ & Unutulduğu Düşünülen Oyunlar \\
\hline KAZAKISTAN & 11 & $\begin{array}{l}\text { Ak törek gök törek, Otluk, İnguluv, Şeşe (Kuyruk yakalama), Kız kovu (Kız } \\
\text { kovalama), Aşı (Beş taş), Yüzük salu (Yüzük saklama), Aşık beygel (Aşıkla } \\
\text { oynanan at yarışı oyunu), Kim birinci (Mendil kapmaca), Aşı atuv (aşık } \\
\text { atma), Aşı (Aşı vurdurma) }\end{array}$ \\
\hline KIRGIZISTAN & 13 & $\begin{array}{l}\text { Kaçmay top, Gökbörü, Kurçak, Akçölmöt, Çoluk, Hasır, Kız kovu, Selkincik, } \\
\text { Bulturmuş oyunları, Atkopça, Top taş (beş taş), Şakek salmayı (Yüzük } \\
\text { saklama), Çüllük (Çelik Çomak) }\end{array}$ \\
\hline TACIKİSTAN & 14 & $\begin{array}{l}\text { Çubuk, Sançil (5 taş), Çarmagz (Aşı çıkarma), Dülço bozi horok bozi (Eşek } \\
\text { oyunu), İlig dangal (Çelik çomak), Lamka (Ayakta kurşun dökülmüş deri } \\
\text { sektirme), Sefador siyador (Bizden size kim gerek), Bamkoşak (Halat çekme), } \\
\text { Dom dom (El çırpma oyunu), Duhtaraki zebo (Cici kız), Haskunak (Zıplama), } \\
\text { Karguşak, Mo poy mazenem (Tekerlemeli oyun), Rubai hobideh (Kuş kondu), }\end{array}$ \\
\hline ÖZBEKISTAN & 15 & $\begin{array}{l}\text { Beş Taş, Aşık, Çüllük (Çelik Çomak), Döndürek (Topaç), Gül ve taş, İp oyunu, } \\
\text { Par (Ayakta kurşun dökülmüş deri sektirme), Mak Mak (Sek Sek), Mangala, } \\
\text { Lale lale (Kuyruk yakalama), Çakallak (Yerden alma), Ayrı (Sapan), Cik (Uzun } \\
\text { eşek), Kazlarım, Eşek oyunu }\end{array}$ \\
\hline MOĞOLİSTAN & 14 & $\begin{array}{l}\text { Taş sürme, Satranca benzeyen kemik oyunu, Teuk (Ayakta kurşun dökülmüş } \\
\text { deri sektirme), Shagai nyaslah (Aşı vurdurma), Ak törek gök törek (Bizden } \\
\text { size kim gerek), Mori uraduulah (Aşılkla oynanan at yarışı oyunu), Shagai } \\
\text { shuuren (Aşı toplama), Şıt sıtav (Yağ satarım), Dokuz kumalak (Mangala), } \\
\text { Mendil kapmaca, Ahşap yapboz, Alag melhi, Bugi niluulek, Dugi daği, }\end{array}$ \\
\hline TUVA & 10 & $\begin{array}{l}\text { Aksak kaday (Kuyruk yakalama), Kamçı, Tevek (Ayakta kurşun dökülmüş deri } \\
\text { sektirme), At çarızı (Aşıkla oynanan at yarışı oyunu), Bilzek çazırağı (Yüzük } \\
\text { saklama), Karak bağlan (Körebe), Atıp oynarı (Aşık vurdurma), Karara (Aşık } \\
\text { toplama), Aram şim şim (Arkadaş), Sek sek, }\end{array}$ \\
\hline HAKASYA & 6 & Bezden kukla, At yarışı, Pre atgi (körebe), Naluptu, Galistal, Tevek \\
\hline ALTAY & 5 & $\begin{array}{l}\text { Küpe yarış1, Taş oyunu, Böğrü ve ursallık (Kuyruk yakalama), Dokuz kumalak } \\
\text { (Mangala), Tevek (Ayakta kurşun dökülmüş deri sektirme), }\end{array}$ \\
\hline YAKUTISTAN & 6 & $\begin{array}{l}\text { Kemik oyunları, Taş oyunu, Tevek, Kamçı, Oyban nohuna (Yerden alma), İnek } \\
\text { yarışı, }\end{array}$ \\
\hline AZERBAYCAN & 19 & $\begin{array}{l}\text { Pergelle, Tut tut, Şakuldak, Ebe mene zu, Düdük, Top top, Pul pul, Dire dövme } \\
\text { (Kemer), Çileme (Ayakta kurşun dökülmüş deri sektirme), Goz goz (Aşık } \\
\text { atma), Enzeli (Birdirbir), Mere mere, Desmal desmal (Yağ satarım), Beş taş, } \\
\text { Yedi ağaç, Sapan, İp oyunu, Aşı, Benövşe benövşe (Bizden size kim gerek) }\end{array}$ \\
\hline DAĞISTAN & 28 & $\begin{array}{l}\text { Çı̆̆ıl, Kazık, Çanak çerbedi, Samahat, Klas(kalas), Duk duk dukdep, } \\
\text { Kızılbayrak, Göz bağlama, Yüzük saklama, İp oyunu, Çelik çomak, Ateş } \\
\text { üstünden atlama, İp üstünden atlama, Ok-yay, Para döndürme, Maskara } \\
\text { maskara, Cincırak döndürme, Yumurta tokuşturma, Uyden uy, Uçurtma, Eşek } \\
\text { müyüş (Uzun eşek), Beş taş, Aşı,, Aylan gavur (Kuyruk yakalama), Ak törek } \\
\text { gök törek (Bizden size kim gerek), Dört taş beş taş, Art anay, Kol yağluk (Yağ } \\
\text { satarım) }\end{array}$ \\
\hline BALKAR & 14 & $\begin{array}{l}\text { Gökte ne var, Ağaç börü, Taban dövüş, Bahuluş, Hoynuk (Topaç), Çüyke } \\
\text { (Çelik çomak), Kim gerek, Tartuşu (Bezirganbaşı), Börk atuv (Yağ satarım), } \\
\text { Sek sek, İp, Lenka (Ayakta kurşun dökülmüş deri sektirme), Sapan, Kol taş, }\end{array}$ \\
\hline KARAÇAY & 18 & Hoynuk (topaç), Taş atma, Cüzük oyun (Yüzük saklama), Çörkük, Teke, Taşa \\
\hline
\end{tabular}




\begin{tabular}{|c|c|c|}
\hline & & $\begin{array}{l}\text { vurup oynama, Kamçı sadak, Suda çöple kayık yarıştırma, Çıkışkııp (sarıllmaca), } \\
\text { Aș1k vurdurma, Regetga (sapan), Amma cukka, Ay melek (Kim gerek), Kol taş, } \\
\text { Pila top, Beş taş, Iz dız (Taş sürme),Kol taş }\end{array}$ \\
\hline BAŞKURDİSTAN & 15 & $\begin{array}{l}\text { Saklambaç, Kelek, } 12 \text { sopa, Sek sek, Yakan top, Çuval yarışı, Yumurta taşıma, } \\
\text { Köşe kapmaca, Kayış (Kemer), Naza (Köprü), Sekiz kapak (Dokuz kiremit), } \\
\text { Kazlar kazlar, Alırım kuş (Kuyruk yakalama), Öküz yüzük (Yüzük saklama), } \\
\text { Kırk taş, }\end{array}$ \\
\hline TATARISTAN & 19 & $\begin{array}{l}\text { Firıldak (düğme oyunu), Şişe çevirmece, Aşık oyunu (kartlarla), Girli oyunu, } \\
\text { Buzlu oyunu, Kız kovalama, Vatık, Şavata (orta top), Sek sek, Tayak (Çelik } \\
\text { çomak), Kazlar kazlar, Mesik sıçkan (Kedi fare), Yılan (Kuyruk yakalama), } \\
\text { Yağlık (Yağ satarım), Kaburgalık (Bizden size kim gerek), Yurt sütiş (Düğüm), } \\
\text { Beş taş, On iki tayak (On iki sopa), Kurşak alış }\end{array}$ \\
\hline ÇUVAŞíSTAN & 16 & $\begin{array}{l}\text { Mungun oyunu, Zincir, Lapta, Beş taş, Sek sek, Göz bağlama, Oy dimeo (Kim } \\
\text { gerek), Köşe kapmaca, Uzun eşek, Alırım kuş (Kuyruk Yakalama), Orta top, } \\
\text { Kaptıç, Hur gaikse (Bazirganbaşı), Tuflilya (Yağ satarım), Pusmak (Yüzük } \\
\text { saklama), Telefon }\end{array}$ \\
\hline KKTC & 25 & $\begin{array}{l}\text { Dokuz kiremit, Ağaç dönmesi, Andrez oyunu, Çift deli linda, Harp oyunu, İp } \\
\text { atlama, Kara kedi oyunu, Köşe kapmaca, Okçuluk, Uçurtma, Zangalak savaşı } \\
\text { (sapan), Plaka (Taş sürme), Alaydan malaydan (Kim gerek), Lingili (Çelik } \\
\text { çomak), Kapıcıbaşı (Bezirganbaşı), Üçgen (Aşık çıkarma), Beş taş, Yağ } \\
\text { satarım, Fincan oyunu (Yüzük saklama), Parmakta ip, Pirilli (Aşı atma), Tahta } \\
\text { tahta ben var (Ayak çekme), Zincirleme, İki parmakta ip çözme, Uzun eşek }\end{array}$ \\
\hline
\end{tabular}

Tablo 7: incelendiğinde geçmişte oynanan 248 oyunun günümüzde oynanmadığının belirtildiği görülmektedir. Geçmişte oynanan kültürel oyunlarının ne kadarının günümüzde unutulmuş olduğu, katılımcıların ifadelerine göre belirlenen oyun sayıları aşağıdaki tabloda verilmiştir.

Tablo 8: Geçmişte Oynanan ve Günümüzde Unutulduğu Düşünülen Oyun Sayıları

\begin{tabular}{lcc}
\hline Ülkeler & Oynanan Oyunlar $\mathbf{( N )}$ & Unutulan Oyunlar $\mathbf{( N )}$ \\
\hline KAZAKISTAN & 18 & 11 \\
KIRGIZISTAN & 20 & 13 \\
TACIKISTAN & 20 & 14 \\
ÖZBEKISTAN & 19 & 15 \\
MOĞOLISTAN & 18 & 14 \\
TUVA & 21 & 10 \\
HAKASYA & 15 & 6 \\
ALTAY & 7 & 5 \\
YAKUTISTAN & 10 & 6 \\
AZERBAYCAN & 32 & 19 \\
DAĞISTAN & 41 & 28 \\
BALKAR & 24 & 14 \\
KARAÇAY & 29 & 18 \\
BAŞKURDISTAN & 26 & 15 \\
TATARISTAN & 33 & 19 \\
ÇUVAŞISTAN & 22 & 16 \\
KKTC & 41 & 25 \\
\hline TOPLAM & $\mathbf{3 9 6}$ & $\mathbf{2 4 8}$ \\
\hline
\end{tabular}

Katılımcıların görüşmelerde 388 oyun adı verdiği, bu oyunlardan 248 oyunun unutulmuş olduğunu düşünüldüğünü belirttiği görülmüştür. Bir diğer ifade ile katılımcılar, geçmişte oynanan kültürel oyunların yaklaşık \%63'ünün unutulduğu görüşündedir. Ayrıca Yakutistan'da oyunların unutulmaması için yasalarla korumaya alındığı ve okullarda eğitim programı içinde öğretildiği belirtilmiştir. Aşağıda katılımcılardan örnek ifadeler verilmiştir. 
Tv: "At çarızı, Bilzek çazırağı. Bazı oyunların daha çok kırsal kesimlerde, köylerde oynandığını görüyorum. Okullarda öğretiyorlar ama günlük hayatta oynamıyorlar. İnternet, bilgisayar, televizyon yüzünden oynamıyor çocuklar."

Yk: “Tevek, Kamçı. Oyunlar hala tam olarak unutulmadı. Köylerde hala oynanıyor. Günümüzde başka oyuncaklar olduğu için rekabet büyüyor. Okullarda çocuklara öğretiliyor. Turnuvalar düzenleniyor. Bu oyunların oynanması yasalaştı."

"91 den beri kanunla kültürel oyunlar öğretilmeye başlandı. O yüzden unutulmadı. Bizim üç oyunumuz uluslararası kimlik kazandı. Bizim oyunlarımız bu sebeplerden dolayı unutulmuyor."

Mğ: "Eskideki oyunlar unutulmuştu fakat artık tekrar oynatılıyor. Bu oyunların unutulmasının sebebi ev işlerinin çok olmasıdır. Çocukların bu sebeple oyun oynayamıyorlar."

"Teuk, Shagai nyaslah. Çocuklar artık bu oyunları unuttu. Ben bu oyunları çok iyi oynarım. Ama kendi çocuklarım dahi bu oyunları oynayamıyor."

Hk: "Naluptu, Galistal, Tevek. Savaş nedeniyle halk dağıldı unutuldu." şeyleri de unuttuk."

"Anne babalarımız bize öğretemedi. Daha çok Sovyet kültürü ağırlıkta bildiğimiz

Tc: “İlig dangal, Lamka unutuldu. Kültürel oyunlar az öğretiliyor. Oyunlar, ortadan gitti. Şimdi yavaş yavaş başlıyoruz öğretmeye fakat oyunlar ortadan gitmiş."

Çv: "Uzun eşek, göz bağlama, beş taş, sek sek, yüzük saklama, telefon, yă̆ satarım, alırım kuş, orta top, $\mathrm{Bu}$ oyunlar çocuklar tarafindan çok fazla bilinmiyor ancak biraz köylerde yaşlilar hatırliyor."

Dğ: "Beş taş, Aşık, Aylan gavur, , Art anay, Kol yağluk, Ak törek gök törek. Oyunların hiç biri oynanmiyor. Bilgisayar, telefon, internet.

B1: "Hoynuk, kol taş, arkan tartgan, aşık, cip tartgan. Unutulmaya başlandı. Sürgüne yollandığımız için. Bunun için yaşlılarla görüşüp oyunları çocuklara anlatıyoruz."

"Şimdikiler oynamıyor. Zaman başkadır. Şimdiki oyuncakları biz de görmedik babalarımız da görmedi. Hepsi satın alma. Evde aşık bulunuyor, fakat torunlar ilgilenmiyor."

Kç: "Şehirlerde yaşayan çocuklar oyun oynamıyor, köyde yaşayan çocuklar bu oyunları oynuyor. Bu yüzden bu oyunlar unutuluyor."

"Hoynuk, Taş atma, Cüzük oyun. Şimdiki çocuklar bizim oynadığımız oyunları oynamıyorlar. Çocuklar televizyonla vakit geçiriyor, gençler de bilgisayarla vakit geçiriyor, sanal oyunları oynuyorlar. Oyuncakları hazır alıyorlar."

"Cüzük oyun, Çörkük, Teke, Iz dız, Kol taş. Çocuklarla okulda bu oyunları oynuyoruz ancak okul dışında bu oyunlar oynanmıyor. Oyunları okullarda çocuklara öğretmenler öğretebilir. Ben öğretmen olarak çocuklara kültürel oyunları öğretiyorum. İş birliği, yardımlaşma gibi değerleri bu oyunlarla öğrendikleri için kültürel oyunları tercih ediyorum. Kültürel oyunlarla beraber çocuklar birçok kavramı öğrenebiliyor."

Tt: "Şimdi çocuklar bilgisayar oynuyorlar. Oyunlar unutuldu."

"Tayak, aşık, sek sek, kazlar kazlar. Bu oyunlar eskiden oynanıyordu şimdi oynanmiyor."

KKTC: "Zangalak savaşı, Plaka, Alaydan malaydan, Lingili. İngilizler sömürge yönetimin de kendi kültürünü yaymak için oyunlarını Türkçe ve Rumcaya çevirdiler ve okullara dağıttılar." 
"Andrez oyunu, Çift deli linda, İp atlama, Köşe kapmaca. Torunlarımın oynadığını görmedim. Hatta benim çocuklarım bile çok oynamıyordu. Şimdi ki çocuklar Bilgisayarlarla elektronik oyunlarla oynuyorlar. O oyunlarla ilgileniyorlar. Biz her şeyimizi kendimiz yapardık."

Araştırmanın beşinci sorusu: Türk ve komşu topluluklarda geçmişte oynanan oyunların unutulmasını önlemeye yönelik görüşler nelerdir?

Görüşmelerde katılımcılara günümüzde unutulduğunu düşündükleri oyunların unutulmaması için neler yapılabileceği sorulmuş ve elde edilen veriler tamalar halinde gruplandırılmıştır. Ortaya çıkan temalar Tablo 9'da verilmiştir.

Tablo 9: Geçmişte Oynanan Oyunların Unutulmasını Önleye Yönelik Görüşler

\begin{tabular}{lll}
\hline Temalar & f & \% \\
\hline Oyunların okullarda öğretimi & 37 & 37 \\
Teknoloji kullanımının sınırlandırılması & 27 & 27 \\
Dede/ninelerin oyunları anlatması & 19 & 19 \\
Kültürel oyuncak üretimi & 13 & 13 \\
Türk toplumlarından öğrenilmesi & 10 & 10 \\
Okul öncesi dönemde kazandırılması & 6 & 6 \\
Kitap yazılması & 6 & 6 \\
Ödüllü yarışmaların düzenlenmesi & 3 & 3 \\
Kongre, sempozyum düzenlenmesi & 2 & 2 \\
Kültür merkezlerinin kullanılması & 2 & 2 \\
Millî bayramlarda oynatılması & 2 & 2 \\
Kanunlar yoluyla korunması & 2 & 2 \\
Sokakta oyunun desteklenmesi & 2 & 2 \\
\hline
\end{tabular}

Katılımcıların verdiği cevaplardan 13 farklı temanın ortaya çıktığı görülmektedir. $\mathrm{Bu}$ temalar arasında en fazla "Oyunların okullarda öğretimi” temasının ifade edildiği belirlenmiştir. İkinci sırada ise "Teknoloji kullanımının sınırlandırılması" teması yer almaktadır. Aşağıda katılımcıların ifadelerinden örnekler verilmiştir.

Mğ: "Kültürel oyunların ve oyuncakların eskisi kadar oynanmamasının sebebi olarak çocukların Barbie bebekler ya da bilgisayar oyunlarını oynaması. O sebeple direk kültürel oyunlara geçiş zor olabilir. $\mathrm{Bu}$ oyunların çocuklar tarafından tekrar oynanabilmesi için bu oyunları oynayanlara ödül verilebilir. Bu sayede bu oyunlar yaygınlaştırılabilir. Anne ve babalar da bu noktada yardımcı olabilirler. Bir ülkenin kültürel oyunları ve oyuncakları çocukların gelişimine katkı sağlar."

Yk: "Çocuklar çok bilgisayarla oynuyorlar. Dışarı çıkıp oyun oynamıyorlar. Biz onları okulda dışarı çıkartıp kültürel oyunlar oynatıyoruz. Hayata bu oyunlarla hazırlanmaları lazım. Bu oyunlar hayata hazırlanmaları için onlara yardım ediyor. Okullarda bu oyunlar verilirse oyunlar çocuklar tarafindan bilinir ve oynanır."

"Her okulda geleneksel kültürel dersler veriliyor. Rus çocuklarına da veriliyor. $\mathrm{Bu}$ derslerde oyuncaklar da gösteriliyor. Okullar ve öğretmenler çocuklara öğretmek zorunda."

"Kurultay gibi projeler yapmak gerek. Öğretmen ve öğrencilere öğretiyorum. Ama bu yeterli olmaz. Daha çok katılımlı kurultaylar olmalı."

Kz: "Çocuklarımız eskiden bahçede oynuyorlardı. Şimdi ise anaokullarına gidiyorlar orada telefon, bilgisayar görüyorlar. Anaokullarında bu oyunları öğretseler güzel olurdu."

"Şimdiki kız çocukları bu oyunları bilmez. Top taş oynardık. Eskiden yöresel bir şey giyip oynardık. Şimdiki çocuklar bilmiyor. Eski dönemdeki o Kırgız ulusal şarkı tekerleme gibi şeyleri sürekli çocuklara anlatıyoruz. Yolluk tastamayı, kaçmay top, gökbörü, kurçak gibi oyunlar oynardık. Yaşlılar daha çok anlatmalı. Çocuklar büyükler anlatırsa öğrenir.” 
Hk: "İnterneti kes, bilgisayarı çöpe at, televizyon olmamalı."

"Kültürümüzü tekrar hatırlamak için diğer Türk Devletlerinin de tarihine bakmalıyız. Çünkü ortak bir tarihimiz var. Oyunlarımızı da bu sayede hatırlar ve yeniden öğreniriz."

Al: "Hayatın gelişmişliği ve globalizm yüzünden unutulmuştur. Turnuvalar yapılarak, ödüller koyularak çocuklara hatırlatılmalıdır. Bu oyunları yüksek seviyelere getirip çocukların dikkatini çekmeliyiz."

Bş: "Köylerdeki çocuklar bu oyunları daha fazla oynuyor. Şehirdeki çocuklar bilgisayar sebebi ile bu oyunlara önem vermiyorlar. Fakat bu oyunlar okullarda öğretilebilir. Hatta bu oyunlar yoluyla matematik gibi konular da öğretilebilir."

"Bu oyunların hepsini oynadım. Çocuklar bu oyunları oynayınca terbiye sahibi olurlar. $\mathrm{Bu}$ oyunlar çocukları terbiyelemede çok önemli. Köydeki çocuklar, şehirdeki çocuklara göre bu oyunları daha fazla oynuyorlar. Şehirdeki çocuklar bu oyunları oynamak için yeterli alan bulamıyorlar. Şehirlerde çocukların oynayacakları yerler olmalı. Kendi bayramlarımızda bu oyunlar oynatılmall." unutulmaz."

Çv: "Torunlar tatile geldiklerinde dedeler, nineler çocuklara bu oyunları oynatırsa

Dg: "Devir başka zaman başka. Çocuklar bilgisayar, telefon yüzünden oyun oynamıyor. Şimdi zamanları olunca topla futbol voleybol oynuyorlar. Küçüklükten beri öğretilmezse unutulur gider. Yaşl1lar birbirine anlatarak öğrenirdik. Yaşlılar çocuklara anlatmalı."

Bl: “Bu oyunların unutulmaması için Türkiye’ye de gitmeliyiz. Kazakistan’a da gitmeliyiz. Türk devletlerine gitmeliyiz."

"Bu oyunlar okullarda gösterilmeli. Öğretmenler çocuklara öğretmeli. Artık herkes okumak istiyor. Ancak öğretmenler öğretebilir. Türkler olarak bir dil konuşsak, bir yaşasak, bir dinde birleşsek çok daha güçlü oluruz."

Kç: "Oyunlar önce öğretmenlere öğretilmelidir. Öğretmenler de çocuklara oynatmalı onlara öğretmelidir."

"Günümüzde kültürel oyunların oynanmamasının sebebi sanal oyunlar ve televizyonun yaygın kullanımıdır. Oyunlar Türk dünyasında oynanmaktadır. Büyüklerden ve yaşlılardan ögrendiğim 200 oyunu kitap haline getirdim. Oyunlar unutulmasın diye derledim bu kitabı. Küçük yaşta çocuklara kültür verilmezse büyük yaşta kazandırılamayacak. Bu nedenle çocuklar ile yaşlilar arasında bağ kurarak kültür aktarımının sağlanması gerekir. Oyunlarımız Türk dünyasının ortak ürünüdür. 5-6 yıllık geçmişe dayanır. Bu geçmiş dilde, dinde, adetlerde ve oyunlarda birliktelik oluşturur."

Öz: “Okullarda öğretmenlerin öğretmesi gerek, mekteplerde öğretilmeli."

Az: "Okullarda bu oyunların tekrar canlandırılması gerekir. Örf ve adetlerimizi kaybetmememiz gerekir. Devlet de yasalarla korumalı."

Tt: "Şimdiki çocuklar çok az oyun oynuyor. Bu oyunları anaokullarında, küçük yaşta öğretmek gerek. Biz öğretmezsek kim öğretecek? Ben burada çalışmasam da gelir öğretirim. (44 Yıl anaokulu öğretmenliği ve müdürlüğü yapmış olan Meskure Şaymardova, kendi çeyizini okula getirmiş ve her gün okula gelerek el yapımı kültürel malzemeleri, oyunları çocuklara anlatıyor.)"

"Oyunları kendi çocukluğumuzdan hatırladığımız kadarıyla öğretiyoruz. Öğretmek için kitaplar yok. Biz oynuyoruz ama çocuklar oyamıyor. Oyunları anlatan kitaplar olmalı." 

öğretti.”

KKTC: "Bu iş okullarda biter. Öğretmenler öğretmeli. Bize de bunları öğretmenler

"Çocuklara oyunların öğretilmesi okul öncesi çağında 4-5 yaşından başlatılırsa sanal ortamdan koparılacağını zannetmiyorum ama bir denge kurulacağına inanıyorum."

"Oynadığımız oyunların çoğu zekâ geliştiricidir. Onun için benim oynadığım oyunları hem kültürümüzü aktarmak açısından hem onları geliştirmek açısından hem de hep birlikte oynamayı öğrenmeleri açısından öğrenmelerinde fayda olduğunu düşünüyorum. Bunun için kültür merkezleri olmalı ve buralarda çocuklara öğretilmeli."

\section{Tartışma Sonuç ve Öneriler}

Türk ve bazı komşu ülke/bölgelerde geçmişten günümüze oynanan oyunların ortaya konulması amacıyla yapılan araştırmada 17 ülke/bölgede 33 şehir, 12 ilçe, 42 köy ve 32 okul ziyareti yapılarak 100 katılımcı ile görüşme yapılmıştır. Görüşmelerde geçmişte oynanan 396 kültürel oyunun ifade edildiği görülmüştür. Bu oyunlardan 112 oyun adının sadece bir ülkede ifade edildiği, geriye kalan 284 oyun adının ise benzer oyunlar olarak ülke/bölgelerde tekrar edildiği görülmüştür. Araştırma ifade dilen oyunlar çeşitlilik açısından ele alındığına toplamda 173 farklı oyun çeşidi tespit edilmiştir. Çocuk oyunları üzerine yapılan benzer araştırmalar incelendiğinde, Türkiye genelinde Onur ve Güney'in (2002) 99, Oğuz ve Ersoy'un (2005) 114, Başal'ın (2007) 21 kültürel oyunu derlediği görülmüştür. Bölgesel olarak yapılan bazı araştırmalarda da Arslan (2017) Sivas ilinin 70, Gökşen (2014) Gaziantep ilinin 35, Aksoy (2014) Karaman ve Konya arasındaki bölgede yaşayan Sarıkeçili yörüklerinin 17, Girmen (2012) Eskişehir ilinin 12, Büyükokutan Töret (2017) Balıkesir ilinin 6 kültürel oyununu derlediği görülmüştür. Ayrıca Şahin (2016) Afganistan Türkmenlerinin çocuk oyunlarını derlediği araştırmasında 20, Jafarova (2010) Azerbaycan çocuk oyunlarını derlediği araştırmasında 12, Yazıcı Ersoy (2010) Başkurdistan çocuk oyunlarını derlediği araştırmasında 10 kültürel oyunu betimlemiştir. Araştırmada 173 farklı oyun çeşidinin belirlenmiş olması, olumlu olarak değerlendirilmektedir. Ancak araştırma sadece gidilen bölgelerle sınırlı olduğu ve bazı oyunların da tamamen unutulmuş olabileceği göz önüne alındığında, bu sayının çok daha yüksek olduğu düşünülmektedir. Araştırmada ortaya çıkan bir diğer önemli sonuç ise 284 defa aynı oyun adlarının (beş taş, yağ satarım vb.) ülkelerde tekrarladığının görülmüş olmasıdır. Kültürel oyunlar, Türk dünyası içinde değerlendirildiğinde, farklı coğrafyalar olmasına rağmen ifade etme ve düşünmedeki birlikteliğin yansıması olarak benzerlik göstermektedir (Gökşen, 2014; Esen, 2008). Bu bağlamda araştırmada sahanın genişletilmesi durumunda, tarihi geçmiş içerisinde ortak kültürel değerlere sahip olunduğu bilinen bu ülkelerde, kültürel oyunlardaki benzerliğin daha da artacağı öngörülmektedir.

Araştırmada katılımcılar bu oyunları sıklıkla dış mekânlarda oynadıklarını, oyunu oynamada 5 saatten daha fazla süre kullandıklarını, oyunlarında kullandıkları oyuncaklarını kendileri yaptıklarını belirtmiştir. Benzer şekilde Arslan (2017) Sivas oyunlarını derlediği araştırmasında, geçmişte oyunlar çocuğun boş zamanının tamamında yer alırken, günümüzde oyun oynama suresinin boş zamanlarının \%66'sını oluşturduğu ve geçmişte oynanan oyunlarda doğal malzemeler kullanılırken, günümüzde hazır oyuncakların kullanıldığı sonuçlarına ulaşmıştır. Artar, Onur ve Çelen'in (2004) çocuk oyunlarının kuşaklar arasında nasıl değiştiğine yönelik yaptıkları araştırmada, geçmişte çocukların çevrelerinde buldukları malzemelerle oyuncak yaparken, günümüzde çocukların hazır plastik oyuncakları kullandıklarını belirlemiştir. Yapılan araştırmalarda geçmişte çocukların doğal ve kendi yaptıkları oyuncaklarla oynadıklarının ortaya konulması, araştırmanın sonucunu desteklemektedir (Lindberg, 2012; Akbulut, 2009; Onur, Çelen ve Artar, 2004). Geçmişte çocuklar oyuncağını kendisi yaparken, akranlarıyla işbirliği, yardımlaşma, paylaşma gibi davranışları kazanarak gelişimini sağlamış ve toplumsallaşma becerisi kazanmıştır (Çelebi Bayar, 2007). Zaman içinde oyuncaklardaki değişimin nedenlerinden en önemlisi, çocukların, günümüzde bireysel ve teknolojik araçlarla oynaması gerçeğidir (Arslan, 
2017). Bu gerçeğin önemli yansımalarından biri, dış mekânda oyun oynama davranışının gittikçe azalmasıdır (Arslan, 2017; Clements, 2004). Alabey ve Yağan Güder'in (2018) İstanbul'da geçmişte oynanan oyunlar ile günümüzde oynanan oyunları karşılaştırma üzerine yaptıkları araştırmada, geçmişte çocuk olan katılımcıların \%85,86'sının, günümüzde ise çocukların sadece \%36,37'sinin dış mekânda oyun oynadığı sonucuna ulaşmıştır. Lindberg'e (2012) göre geçmişte oynanan oyunlarla günümüzde oynanan oyunlar arasındaki en büyük fark, dış mekânlarda oynanan oyunlar üzerindedir. $\mathrm{Bu}$ durum, araştırma sonucunun geçmişte oyunların sıklıkla dış mekânda oynandığı bulgusu ile örtüşmektedir.

Araştırmada katılımcıların çocukken oynadıkları oyunları en fazla arkadaş, daha sonra ağabey/abla veya anne/babalarından öğrendiklerini görülmüştür. Benzer şekilde Artar, Onur ve Çelen, (2004) araştırmalarında, çocukların oyunları kendilerinden büyük olan çocuklardan veya arkadaşlarından öğrendikleri sonucuna ulaşmıştır. Alabay ve Yağan Güder (2018) geçmişte çocuklar akranları ile oynarken günümüzde tek başına bireysel oyunlar oynadıklarını belirtmiş̧ir. Koçyiğit ve Baydilek-Başara (2015) okul öncesi dönemdeki çocukların oyun algılarını incelediği araştırmasında, çocukların oyunlarını evde yalnız olarak oynadığı sonucuna ulaşmıştır. Özellikle çocuklardaki bilgisayar, televizyon gibi ekranlara olan bağımlılığın, çocukları grup oyunlarına değil tek başına oyun oynamaya yönelttiği görülmektedir (Yavuzer, 1993; Yavuzer, 2003). Bu bağlamda yapılan araştırma, geçmişte çocukların arkadaşlarıyla birlikte oyun oynadıklarını ortaya koymuştur.

Araştırmada geçmişte oynanan oyunların çoğunun (\%63) günümüzde çocuklar tarafindan oynanmadığı ve unutulduğu görüşü ifade edilmiştir. Tuğrul, Ertürk, Özen Altınkaynak ve Güneş (2014) kuşaklar arası oyunlar üzerine yaptıkları araştırmada ortaya konulan, günümüzde çocukların kültürel oyunlar yerine bireysel olarak bilgisayar oynamayı tercih ettikleri, bu yüzden geçmişte oynanan oyunların günümüzde oynanmadığı sonucu, yapılan araştırma sonucunu desteklemektedir. Kültürün önemli unsurlarından biri olan oyunlar, şehirleşme ile birlikte değişim sürecine girmiş̧ir. Şehirleşme ile birlikte gelen teknolojinin de kullanımıyla, oyunlar iç mekânlarda oynanmaya başlanmış, dış mekânlarda oynanan oyunlar unutulmaya başlanmıştır (Öz Pektaş, 2017). Dolayısıyla teknolojiyle birlikte gelen yeni oyun ve oyuncaklar, kültürel oyunların gelecek nesillere aktarımını engellemiş ve bu oyunlar günümüzde unutulmaya başlanmıştır (Öz Pektaş, 2017; Başal, 2007; Artar, Onur ve Çelen, 2004 ). Araştırmada katılımcıların ifadelerinden de anlaşıldığ gibi özellikle teknoloji kullanımının kültürel oyunların unutulması üzerinde etkili olduğu görülmektedir.

Geçmişte oynanan oyunların unutulmasını önlemeye yönelik 13 farklı temanın ortaya çıktığı, bu temalardan oyunların okullarda öğretilmesi ve teknoloji kullanımının sınırlandırılması temalarının yüksek oranda ifade edildiği belirlenmiştir. Bunların dışında dede/ninelerin oyunları anlatmas1, kültürel oyuncak üretimi, Türk toplumlarından öğrenilmesi, okul öncesi dönemde kazandırılması, kitap yazılması, ödüllü yarışmaların düzenlenmesi, kurultay/sempozyum düzenlenmesi, kültür merkezlerinin kullanılması, millî bayramlarda oynatılması, kanunlar yoluyla korunması ve sokakta oyunun desteklenmesi temaları ortaya çıkmıştır. İlgili alan yazına bakıldığında, ortaya çıkan temaların desteklendiği görülmektedir. Çocukların topluma ait bir birey olmalarını sağlayan oyunlar, çocukların kültürel gelişimlerini sağlamayla birlikte kültürel mirasımız olan oyunlarında korunmasını sağlamaktadır (Bay, 2018). Çocukların kültürel oyunları bilmemesi ve oynamaması, toplumsal kimlik kazanımlarını olumsuz etkilemektedir (Özden Gürbüz, 2016; Fırat, 2013). Bu nedenle kültür, eğitimin bir unsuru olarak değerlendirilmeli ve okullar, kültür aktarımını sağlamalıdır (Akyüz, 2016;Toksoy, 2010). Bir başka ifadeyle, kültürel mirasımız olan kültürel oyunların, yaratıcı uygulamalarla millî eğitim sürecinde bir araç olarak kullanılması sağlanmalıdır (Sağlam, 1997). Toplumların birlikteliğini ve devamlılığını sağlayan kültürün çocuklara aktarılması tesadüflerle değil, ancak millî bir eğitim politikasıyla mümkündür (Bay, 2018). Bu sağlanmadığı taktirde, kültür yok olmaya başlayacaktır (Akyüz, 2016). 
Kültürel oyunların yok olmaya başladığının bir diğer göstergesi de teknolojik araçların artan kullanımıdır. Çocuklar üzerinde birçok sağlık sorunlarının oluşmasına neden olan teknolojik araç kullanımı (Egemen, Yılmaz ve Akil, 2004), çocukların dışarıda oynama davranışlarını da oldukça azaltmıştır (Lindberg, 2012; Maynard, 2010; Kinoshita, 2009; Clements, 2004; Özdirenç, Özcan, Akın, Gelecek, 2005). Dolayısıyla televizyon, bilgisayar gibi araçların kullanımı kültürel oyunların hızla unutulmasına neden olmaktadır. $\mathrm{Bu}$ bağlamda ailelerin teknolojik aletlerin kullanımını sınırlandırması gerekmektedir. Aile büyüklerinin çocukluk zamanlarında oynadıkları oyunları çocuklarına anlatmaları, öğretmeleri, oynamaları için imkânlar oluşturmaları ve çocuklarını bu yönde desteklemeleri gerekmektedir (Alabay ve Yağan Güder, 2018). Çünkü günümüzde çocuklar kültürel oyunları arkadaşlarından değil, ancak aile büyüklerinden öğrenebilmektedir (Lindberg, 2012).

Çocukların kültürel oyunları öğrenmesine engel olan diğer bir unsurda, endüstriyel oyuncakların hazır olarak çocuklara sunulmasıdır (Akbulut, 2009). Çocukların yaratıcılıklarını ve hayal güçlerinin kullanımını sınırlayan hazır oyuncaklar, kültürel oyunların da unutulmasına neden olmaktadır. Oysaki kültürel oyunlar gibi bu oyunların içinde şekillenen oyuncaklarda kültürün taşıyıcılı̆g 1 görevini görmektedir. Bu nedenle eğitim ve sürdürülebilir çalışmalar yoluyla kültürel oyuncakların, çocukları sürekli içine çeken oyuncak pazarında daha ilgi çekici hale getirilerek talep görmesi sağlanmalıdır (Karaman ve Nas, 2006).

Oyunlar, geçmişten günümüze birbiriyle ortak yaşantıları ve paylaşımları olan toplumların ortak kültürel değerlerini yansıtmaktadır (Yazıcı Ersoy, 2010). Afganistan, Azerbaycan, Başkurdistan ve Türkiye çocuk oyunlarının çok yüksek oranda benzerlik göstermesi de bu yüzdendir (Şahin, 2016; Jafarova, 2010; Yazıcı Ersoy, 2010). Araştırmada da bazı ülkelerin komşu olması sebebiyle etkileşime girmesi, bazı ülkelerinde ortak tarihe sahip Türk toplumları olması nedeniyle, oyunlarda yüksek düzeyde benzerlik olduğu görülmüştür. Ortak kültürel değer olan oyunların, yine bu toplumlar arasında paylaşım ve işbirliği ile korunmasının mümkün olacağı düşünülmektedir. Nitekim görüşmelerde de katılımcılar tarafindan bu ülkelerden unutulan oyunların tekrar hatırlanabileceği tema olarak ifade edilmiştir.

Oyun, çocuğun gerçek yaşamda en etkili öğrenme aracıdır. Yaşama dönük deneyimleri oyun sayesinde kazanırken aynı zamanda bilişsel, sosyal, duygusal, dil ve fiziksel gelişimini de desteklemektedir (Girmen, 2012). Bay'ın (2018) okul öncesinde kültürel oyunların aktarımı üzerine yaptığı araştırmasında çocukların kültürel oyunları öğrendiği ve severek oynadığ1 görülmüştür. Küçük yaşlarda çocukların deneyimleyerek öğrendiği bilgiler kalıcı olmaktadır (Şahin, Güven ve Yurdatapan, 2011; Senemoğlu, 1994). Bu bağlamda kültürel oyunların gelecek nesillere aktarımının, okul öncesi dönemde verilemeye başlanmasının etkili ve verimli olacağı düşünülmektedir.

Unutulmuş oyunları gün yüzüne çıarmanın önemli yollarında biriside oyunların derlenmesidir. Kültürel oyunların nasıl oynandığını bilen yetişkinlerin sayıları, her geçen gün azalmaktadır. Bu oyunların oynanış şekillerinin, kurallarının belirlenmesi ve yazılı hale getirilmesi kültürel oyunların korunması ve gelecek nesillere aktarılması için önemlidir (Arslan, 2017). Çağın getirdiği değişimler karşısında kültürel oyunlar kayıt altına alınmadığı taktirde yok olmaya başlayacaktır (Jafarova, 2010).

Kültürün yaşatılmasının önünde bir engel olan kentleşme ve beraberinde getirdikleri, mücadele edilmesi gereken diğer bir durumdur (Öz Pektaş, 2017; Artar, Onur ve çelen, 2004). Geçmişte dışarıda ve geniş alanlarda oynanan oyunlara günümüzde mekân olarak yeterli imkân bulunmamaktadır. Bunun bir yansıması olarak da çocuklar evlerinden çıkmamaktadır (Arslan, 2017). Sokakları kaplayan arabalar, trafik, yüksek katlı binalar ve güvenlik sorunları, çocukların elinden oyun oynama haklarını almaktadır (Çakırer Özservet, 2015). Dolayısıyla sokaklarda ve bahçelerde oynanan oyunlar unutulmaya başlanmıştır (Öz Pektaş, 2017). Bu nedenle kültürel

\section{Turkish Studies}

Volume 14 Issue 7, 2019 
oyunların yeniden hatırlanması oynanması için sokakların eskiden olduğu gibi insani boyuta getirilmesi ve kültürel oyun mekanları olarak yeniden düzenlemesi ve tasarlanması gerekmektedir (Çakırer Özservet, 2015).

Ayrıca, kültürel oyunlar üzerine okullar ya da diğer kurumlar tarafindan yarışmaların yapılması; 23 Nisan Ulusal Egemenlik ve Çocuk Bayramı, 19 Mayıs Atatürk’ü Anma Gençlik ve Spor Bayramı, nevruz gibi millî bayramlarda oyunların oynanmasının teşvik edilmesi; kültür merkezleri oluşturularak bu merkezlerde oyunların öğretilmesi ve yasalar yoluyla oyunların korumaya alınmasının da kültürel oyunların hatırlanmasına ve yeniden oynanmasına katk1 sağlayacağı düşünülmektedir.

Sonuç olarak 17 ülkeyi kapsayan geniş bir sahada ve çok zorlu şartlarda yapılan bu araştırmada 100 katılımc1 ile yapılan görüşme sonrasında kültürel oyunların neler olduğu ve bu oyunların özellikleri, nasıl öğrenildiği, hangilerinin unutulduğunun düşünüldüğü ve unutulmaması için neler yapılabileceği ortaya konulmaya çalışılmıştır. Araştırmanın sınırlılıkları doğrultusunda geçmişte oynanan birçok oyun ülkelere göre belirlenmiş, bu oyunların büyük oranda ülkeler arasında benzerlik gösterdiği görülmüş, oyunların sıklıkla dış mekânlarda, zaman sınırlaması olmadan, el yapımı doğal oyuncaklarla oynandığı, oyunların arkadaşlardan öğrenildiği belirlenmiştir. Tespit edilen oyunların çoğunluğunun (\%63) ise unutulduğunun ifade edildiği araştırmada, kültürel oyunların unutulmamasına yönelik 13 farklı temanın ortaya çıktığ görülmüştür. Araştırmanın ortaya koyduğu sonuçlarının, kültürel oyunların günümüzdeki durumunu görme açısından bir şemayı ortaya koyduğu ve yok olmaya yönelik ciddi risk altında olduğunu gösterdiği düşünülmektedir. Bu doğrultuda katılımcıların ifadeleriyle ortaya çıkan temalar alınabilecek tedbirler açısından oldukça önem arz etmektedir.

\section{Öneriler}

Yapılan araştırma sonuçlarına dayalı olarak aşağıdaki önerilerde bulunulmuştur;

- Araştırmacılar tarafindan diğer Türk ve komşu toplumları da içine alan saha araştırmalarının yapılarak kültürel oyunların daha kapsamlı olarak ortaya konulması,

- Oyunların derlenme çalışmalarının yanı sıra oyunların eğitim kurumlarında kullanımının sağlanmasına yönelik kaynak kitapların yazılması,

- Kültürel oyunların oynanmasını sağlayacak olan oyuncakların özgün tasarımlarla çocukların ilgisini çekecek hale getirilerek bireysel ve okullarda kullanım için kitler halinde hazırlanmasi,

- Okul öncesi eğitimden başlayarak eğitim kademelerinin programlarının, kültürel oyunların eğitimde bir yöntem olarak kullanılmasının yanı sıra doğrudan öğretimiyle ilgili düzenlenmelerin yapılması,

- Kuruluş amaçları arasında kültür aktarımının da yer aldığı Halk Eğitim Merkezlerinde kültürel oyunların öğretimi üzerine kursların açılması,

- Ailelerin kültürel oyunları çocuklarına aktarabilmeleri için aile eğitim seminerleri ile gerekli desteğin sağlanması,

- Eğitim kurumlarında millî bayramlarda kültürel oyunların oynatılmasına ve kurum içinde veya kurumlar arasında müsabakalar düzenlenmesine yönelik kararlar alınması,

- Yerleşim alanlarında ve parklarda çocukların kültürel oyunları oynamaya teşvik edecek güvenli ortamların hazırlanması önerilmektedir. 


\section{KAYNAKÇA}

Adak Özdemir, A. \& Ramazan, O. (2012). Oyuncağa çocuk, anne ve öğretmen bakış açısı. Eğitim Bilimleri Araştırma Dergisi, 2(1), 2-16.

Akbulut, D. (2009). Günümüzde geleneksel oyuncaklar. Millî Folklor, 84, 182-191.

Aksoy, H. (2014). Çocuk oyunlarının işlevleri: Sarıkeçili yörük çocuk oyunları. Milli Folklor, 26(101), 265-276.

Akyüz, Y. (2014). Türk eğitim tarihi. Ankara: Pegem Akademi Yayıncılık.

Akyüz, Y. (2016). Eğitimin kültür ve uygarlıkları geliştirme ve yeni nesillere aktarma işlevi. Türkiye Ĕ̈itim Dergisi, 1(1), 1-18.

Alabay, E., Yağan Güder, S. (2018). Changing Face of Plays: A Comparative Research of Childhood Plays of Older Adults and Plays of Today's. Bartın Üniversitesi Ë̈itim Fakültesi Dergisi, 7(1), 237-259.

And, M. (2003). Oyun ve bügü: Türk kültüründe oyun kavramı. İstanbul: Yap1 Kredi Yayınlar1.

Arslan, A. (2017). Geçmişten günümüze uzanan süreçte oyun ve oyuncaklardaki farklılaşmanın incelenmesi (Sivas ili örneklemi). International e-Journal of Educational Studies (IEJES), 1(2), 69-87.

Artar, M., Onur, B., Çelen, N. (2004). Çocuk oyunlarında üç kuşakta görülen değişimler: Kırsal kesimde bir araştırma. B. Onur ve N. Güney (Ed.). Türkiye'de çocuk oyunları: araştırmalar, içinde. (s. 124-130). Ankara: Kök Yayıncılık.

Başal, H. A. (2010). Geçmişten Günümüze Türkiye'de Geleneksel Çocuk Oyunları. İstanbul: Morpa Kültür Yayınları.

Başal, H. A. (2007). Geçmiş yıllarda Türkiye'de çocuklar tarafindan oynanan çocuk oyunları. Uludağ Üniversitesi Eğitim Fakültesi Dergisi, 20(2), 243-266.

Batur, Z., Beştaş, M. (2011). Divanu Lugati-t Turk’te cocuk dunyası ve cocuk eğitimi. Turkish Studies, 6(2), 247-262.

Bay, D. N. (2018). Okul Öncesi Eğitimde Bir Kültür Aktarımı: Millî Oyunlar. e-Uluslararası Eğitim Araştırmaları Dergisi, 9(2), 82-104.

Bay, D.N., Turan, S., Bay, Y. (2015). Türk Dünyasında Çocuk Oyunları: Bir Saha Çalışması. I. Uluslararası Türk Dünyası Çocuk Oyun ve Oyuncakları Kurultayı 14-17 Mayıs 2015 (ss. 175-185). Eskişehir Osmangaz Üniversitesi, Eskişehir, Türkiye.

Bozkaya, J. (1992). Çocuğun oyun mekânları için olanakların araştırılması. (Yayınlanmamış Yüksek Lisans Tezi). KTÜ Fen Bilimleri Enstitüsü, Mimarlık Anabilim Dalı, Trabzon.

Büyükokutan Töret, A. B. (2017). Balıkesir oyun evlerinde oynanan geleneksel çocuk oyunlarının işlevleri üzerine bir değerlendirme. Pamukkale University Journal of Social Sciences Institute/Pamukkale Üniversitesi Sosyal Bilimler Enstitüsü Dergisi, (28), 19-30.

Cengiz, S. A. (1997). Karadeniz Ereğli örneğinde çocuk oyunlarının halk bilim açısından değerlendirilmesi. Çocuk Kültürü, I. Ulusal Çocuk Kültürü Kongresi Bildirileri. Ankara: Ankara Üniversitesi Çocuk Kültürü Araştırma ve Uygulama Merkezi Yayınları, s. 441-476.

Egemen, A., Yılmaz, Ö., Akil, İ. (2004). Oyun, oyuncak ve çocuk. ADÜ Tıp Fakültesi Dergisi, $5(2), 39-42$. 
Clements, R. (2004). An investigation of the status of outdoor play. Contemporary Issues in Early Childhood, 5(1), 68-80.

Çakırer Özservet, Y. (2015). Geleneksel çocuk oyunları için sokak temelli geleneksel oyun alanlarının yeniden keşfi. I. Uluslararası Türk Dünyası Çocuk Oyun ve Oyuncakları Kurultayı Tam Metin Bildiri Kitabı, içinde(s. 264-269). Ankara: Pegem Akademi Yayıncılık, Eskişehir.

Çelebi Bayar, D. (2007). Türkiye ve Azerbaycan'daki çocuk oyunları ve oyuncaklarının karşılaştırmalı incelemesi. (Yayınlanmamış Yüksek Lisans Tezi). Muğla Üniversitesi, Sosyal Bilimler Enstitüsü, Çağdaş Türk Lehçeleri ve Edebiyatları Anabilim Dalı, Muğla.

Ekiz, D. (2009). Bilimsel araştırma yöntemleri. Ankara: Anı yayıncılık.

Esen, M. A. (2008). Geleneksel çocuk oyunlarının eğitimsel değeri ve unutulmaya yüz tutmuş Ahıska oyunları. Uludă̆ Üniversitesi Eğitim Fakültesi Dergisi, 21(2), 357-367.

Fırat, H. (2013). Çocuk oyunlari-eğitim ilişkisi: Bezirgan başı örneği. Electronic Turkish Studies, 8(13), 885-896.

Girmen, P. (2012). Eskişehir folklorunda çocuk oyunları ve bu oyunların yaşam becerisi kazandırmadaki rolü. Milli Folklor, 24(95), 263-273.

Glesne, C. (2015). Nitel araştırmaya giriş. (Çev. Ed. Ali Ersoy ve Pelin Yalçınoğlu). Ankara: Anı Yayıncilik.

Gökşen, C. (2014). Oyunların çocukların gelişimine katkıları ve Gaziantep çocuk oyunları. Atatürk Üniversitesi Türkiyat Araştırmaları Enstitüsü Dergisi, (52), 229-259.

Huizinga, J. ve Ludens, H.(1995). Oyunun toplumsal işlevi üzerine bir deneme. (Çev. M. Ali Kılıçbay). İstanbul: Ayrıntı Yayınları.

Işıktekiner, S. F. ve Altun, A. S. (2011). Hastane okullarında sorunlar. Eğitim ve Bilim,36 (161), 318-331

Jafarova, Ġ. (2010). Azerbaycan Geleneksel Çocuk Oyunları. Acta Turcica Çevrimiçi Tematik Türkoloji Dergisi, II/1, 244-261.

Kaleli Yılmaz, G. (2014). Durum çalışması. In M. Metin (Ed.), Kuramdan uygulamaya eğitimde bilimsel araştırma yöntemleri, içinde (ss. 261-285). Ankara: Pegem Akademi Yayıncılık.

Karaman, G., Nas, E. (2006). Çorum İskilip’te geçmişten günümüze aktarılan bir miras: Ahşap oyuncaklar. Karadeniz Uluslararası Bilimsel Dergi, 4(14), 103-116.

Kaya, D. (2009). Sivas'ta çocuk oyunları. Uluslararası Halk Dünyasında Eğlence Sempozyumu, 11-13 Aralık, Kocaeli.

Kayar, P. (2008). Van’ın geleneksel çocuk oyunları ve bu oyunların eğitsel yönden incelenmesi. (Yayınlanmamış Yüksek Lisans Tezi). Yüzüncü Yıl Üniversitesi, Sosyal Bilimler Enstitüsü, Türkçe Eğitimi Anabilim Dalı, Van.

Kinoshita, I. (2009). Charting generational differences in conceptions and opportunities for play in Japanese neighborhood, Journal of Intergenerational Relationships, 17(1), 53-77.

Koçyiğit, S., Baydilek-Başara, N. (2015). Okul öncesi dönem çocuklarının oyun algılarının incelenmesi. Yüzüncü Yıl Üniversitesi Eğitim Fakültesi Dergisi, 12(1), 1-28. 
Koçyiğit, S., Tuğluk, M. N., \& Kök, M. (2007). Çocuğun gelişim sürecinde eğitsel bir etkinlik olarak oyun. Atatürk Üniversitesi Kazım Karabekir Ĕgitim Fakültesi Dergisi, (16), 324342 .

Lindberg, E. N. (2012). Çocuk Oyunlarında İki Kuşakta Görülen Değişim. International Online Journal of Educational Sciences, 4(2), 395-410.

Maynard, R. (2010). Computers and young children. Canadian Children, 35(1), 15-18.

McMillan, J., \& Schumacher, S. (2006). Research in education. (6th ed.) Boston: Pearson Education.

Mesleki Eğitim ve Öğretim Sisteminin Güçlendirilmesi Projesi (MEGEP). (2007). Çocuk Gelişimi ve Eğitimi, Oyun Etkinliği -I, Ankara: MEB Yayınları.

Miles, M. B., Huberman, A. M. (1994). Qualitative data analysis. (2nd Ed.). Thousand Oaks, California: Sage Publications.

Oğuz, Ö. ve Ersoy, P. (2005). Türkiye'de 2004 yılında yaşayan geleneksel çocuk oyunları. Ankara: Gazi Üniversitesi Türk Halkbilimi Araştırma ve Uygulama Merkezi Yayınları:4.

Oksal, A. (2004). Kuşaklararası oyun: yetişkin ve çocuk kültürü arasında bir köprü. B. Onur ve N. Güney (Ed.). Türkiye'de çocuk oyunları: Araştırmalar içinde. (s. 102-106). Ankara: Kök Yayıncılik.

Onur, B., Çelen, N., Artar, M. (2004). Türkiye'de geleneksel oyuncaklar: köy-kent karşılaştırması. B. Onur ve N. Güney (Ed.). Türkiye'de Çocuk Oyunları: Araştırmalar içinde. (s. 131-137). Ankara: Kök Yayıncılık.

Onur, B., Çelen, N., Çok, F., Artar, M., Sener-Demir, T. (1997). Türkiye'de iki kentte annelerin bakış açısıyla çocukların oyuncak gereksinmesi. Ankara Üniversitesi Eğitim Bilimleri Fakültesi Dergisi, 30(1), 45-74.

Onur, B., \& Güney, N. (2002). Türkiye'de çocuk oyunları: Derlemeler. Ankara: Ankara Üniversitesi Çocuk Kültürü Araştırma ve Uygulama Merkezi Yayınları.

Öz Pektaş, H. (2017). Geleneksel çocuk oyunlarının modern eğitimde kullanılması. Journal of International Social Research, 10(49), 478-490.

Özden Gürbüz, D. (2016). Geleneksel çocuk oyunları ve eğitimsel işlevleri: Emirdağ örneği. Turkish Studies, 11(14), 529-564.

Özdirenç, M., Özcan, A., Akin, F., Gelecek, N. (2005). Physical fitness in rural children compared with urban children in Turkey, Pediatrics International, 47, 26-31.

Özhan, M. (1997). Türkiye'de çocuk oyunları kültürü. (1. Baskı). Ankara: Feryal Matbaası.

Rossie, J-P. (2005). Toys, play, Culture and society: an anthropological approach with reference to North Africa and the Sahara. Stockholm: Stockholm International Toy Research Centre (SITREC). Stockholm (S): KTH (The Royal Institute of Technology)

Sağlam, T. (1997). Türk Çocuk Oyunlarında Ritüel Ögeler. Çocuk Kültürü, I. Ulusal Çocuk Kültürü Kongresi Bildirileri, (s.416-441).

Senemoğlu, N. (1994). Okulöncesi eğitim programı hangi yeterlikleri kazandırmalıdır?. Hacettepe Üniversitesi Eğitim Fakültesi Dergisi, 10(10), 21-30.

Spodek, B. \& Saracho, O. N. (2003). Early childhood educational play. Contemporary perspectives on play in early childhood education. O. N. Saracho ve B. Spodek (Ed.). pp. 171-179. United States of America: Age Publishing Inc. 
Sun, M., Seyrek, H. (1997). Okulöncesi eğitimde oyun. İzmir: Müzik Eserleri Yayınları.

Şahin, S. (2016). Afganistan Türklerinin kültürlerinde çocuk oyunları. Selçuk Üniversitesi Türkiyat Araştırma Dergisi, 40(1), 261-271.

Şahin, F., Güven, İ., Yurdatapan, M. (2011). Proje tabanlı eğitim uygulamalarının okul öncesi çocuklarında bilimsel süreç becerilerinin gelişimine etkisi. Marmara Üniversitesi Atatürk Eğitim Fakültesi Eğitim Bilimleri Dergisi, 33(33), 157-176.

Toksoy, A. C. (2010). Yarışma niteliği taşıyan geleneksel çocuk oyunları. Çevrimiçi Tematik Türkoloji Dergisi, 2(1), 205-220.

Tören, A. (2011). Erzincan'dan derlenen çocuk oyunlarının çocuk eğitimindeki yeri. (Yayınlanmamış Yüksek Lisans Tezi). Erzincan Üniversitesi Sosyal Bilimler Enstitüsü Türkçe Eğitimi Anabilim Dalı, Erzincan.

Tuğrul, B. (2010). Oyun temelli öğrenme. Okul öncesinde özel ögrretim yöntemler. (Ed. R. Zembat). Ankara: An1 Yayınc1lik. ss. 187-220.

Tuğrul, B., Ertürk, H. G., Özen Altınkaynak, Ş., \& Güneş, G. (2014). Oyunun üç kuşaktaki değişimi. The Journal of Academic Social Science Studie, 27, 1-16.

Yavuzer, H.(1993). Ana baba ve Çocuk. Yedinci Bask1. İstanbul: Remzi Kitabevi.

Yavuzer, H. (2003). Doğal Harika Bir Tedavi: Oyun. Evde ve Okulda Mutlu Çocuk Yetiştirmenin Temelleri. (4. Baskı). İstanbul: Çocuk ve Aile Kitapları

Yazıcı Ersoy, Y. (2010). Başkurt Çocuk Oyunları. Milli Folklor, 22(86), 75-86.

Yıldırım, A., Şimşek, H. (2013). Sosyal bilimlerde nitel araştırma yöntemi. (8. Baskı). Ankara: Seçkin Yayıncılik.

Yörükoğlu, A. (2004). Çocuk ruh sağllğg. İstanbul: Özgür Yayınları. 